Hydrol. Earth Syst. Sci. Discuss., 6, 5205-5241, 2009 www.hydrol-earth-syst-sci-discuss.net/6/5205/2009/ (C) Author(s) 2009. This work is distributed under the Creative Commons Attribution 3.0 License.
Hydrology and Earth System Sciences Discussions

Papers published in Hydrology and Earth System Sciences Discussions are under open-access review for the journal Hydrology and Earth System Sciences

\title{
Iterative approach to modeling subsurface stormflow based on nonlinear, hillslope-scale physics
}

\section{J. H. Spaaks ${ }^{1}$, W. Bouten ${ }^{1}$, and J. J. McDonnell ${ }^{2}$}

${ }^{1}$ University of Amsterdam, Institute for Biodiversity and Ecosystem Dynamics, Computational Geo-Ecology - Nieuwe Achtergracht 166, 1018WV Amsterdam, The Netherlands

${ }^{2}$ Oregon State University, Department of Forest Engineering - 015 Peavy Hall, Corvallis OR 97331-5706, USA

Received: 16 July 2009 - Accepted: 21 July 2009 - Published: 3 August 2009

Correspondence to: J. H. Spaaks (jspaaks@uva.nl)

Published by Copernicus Publications on behalf of the European Geosciences Union.

\section{HESSD}

$6,5205-5241,2009$

Hillslope-scale, nonlinear model of subsurface stormflow

J. H. Spaaks et al.

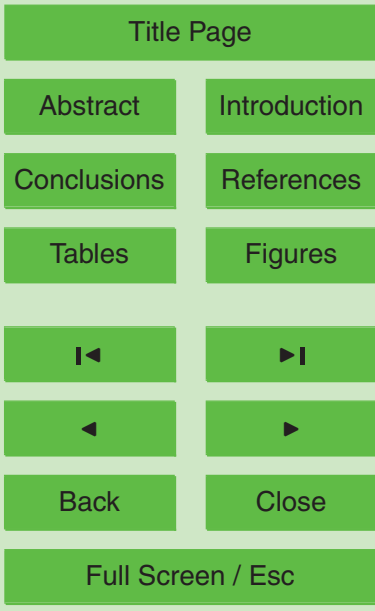

Printer-friendly Version

Interactive Discussion 


\section{Abstract}

Soil water transport in small, humid, upland catchments is often dominated by subsurface stormflow. Recent studies of this process suggest that at the plot scale, generation of transient saturation may be governed by threshold behavior, and that transient 5 saturation is a prerequisite for lateral flow. The interaction between these plot scale processes yields complex behavior at the hillslope scale. We argue that this complexity should be incorporated into our models. We take an iterative approach to developing our model, starting with a very simple representation of hillslope rainfall-runoff. Next, we design new virtual experiments with which we test our model, while adding more cycles, corresponding to three different hillslope-scale, lumped models. Model ${ }_{1}$ is a linear tank model, which assumes transient saturation to be homogeneously distributed over the hillslope. Model $_{2}$ assumes transient saturation to be heterogeneously distributed over the hillslope, and that the spatial distribution of the saturated zone does in space and in time. We found that the homogeneity assumption underlying Model $_{1}$ resulted in hillslope discharge being too steep during the first part of the rising limb, but not steep enough on the second part. Also, peak height was underestimated. The additional complexity in Model $_{2}$ improved the simulations in terms of the fit, but not in terms of the dynamics. The threshold-based $\mathrm{Model}_{3}$ captured most of the hydrograph dynamics (Nash-Sutcliffe efficiency of 0.98). After having assessed our models in a lumped setup, we then compared Model $_{1}$ to $\mathrm{Model}_{3}$ in a spatially explicit setup, and evaluated what patterns of subsurface flow were possible with model elements of each type. We found that Model $_{1}$ tended to generate relatively smooth, steady state-like 25 spatial patterns. Model $_{3}$ generated more complex patterns, in which lateral flow could be concurrently increasing and decreasing in different parts of the hillslope. We realize that the concepts proposed in this manuscript do not represent the only way in which nonlinear dynamics may be implemented in a model of subsurface stormflow. However,
HESSD

$6,5205-5241,2009$

Hillslope-scale, nonlinear model of subsurface stormflow

J. H. Spaaks et al.

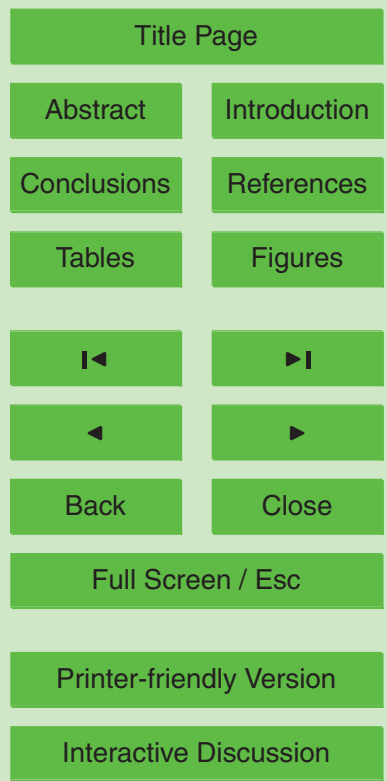


we believe that development of new model structures and the subsequent confrontation of model results with existing preconceptions will lead to a better understanding of subsurface stormflow and catchment runoff dynamics.

\section{Introduction}

5 Over the past decades, much time and effort has been spent in researching how water moves through the soil in small, humid, upland catchments. Under these circumstances, we often have to deal with the mostly unknown effects of a shallow soil, that is usually underlain by an impermeable layer of (for example) bedrock or glacial till. Due to the consolidated nature of this material, these regions are usually dominated by steep slopes of $30^{\circ}$ or more. Together, these conditions often lead to subsurface stormflow being the main contributor to storm discharge in these areas (Hursh and Brater, 1941; Hursh, 1944; Hewlett and Hibbert, 1967; Weiler et al., 2005). Since the 1930 s, various mechanisms of flow have been proposed to describe water transport in these catchments, e.g. overland flow (Horton, 1933), partial contributing areas (Bet15 son, 1964), variable source areas and translatory flow (Hewlett and Hibbert, 1967), return flow and direct precipitation onto saturated areas (Dunne and Black, 1970), saturated wedge development (Weyman, 1973), flow through pipes and macropores (Jones, 1971; Mosley, 1979), transmissivity feedback (Rodhe, 1987; Seibert et al., 2003), flow at the soil-bedrock interface (McDonnell, 1990; Peters et al., 1995; Tani,

fill-and-spill concept (Tromp-van Meerveld and McDonnell, 2006b).

In spite of this apparent abundance of ideas, many of our models still rely on a number of assumptions such as (McDonnell, 2003): (i) surface topography driven drainage direction; (ii) gradually declining lateral hydraulic conductivity with increasing depth;

(iii) spatially more or less uniform water table response to precipitation and (as a result) development of a saturated wedge from the valley upwards. However, convincing field evidence has been presented in recent years which suggests that, for subsurface

HESSD

$6,5205-5241,2009$

Hillslope-scale, nonlinear model of subsurface stormflow

J. H. Spaaks et al.

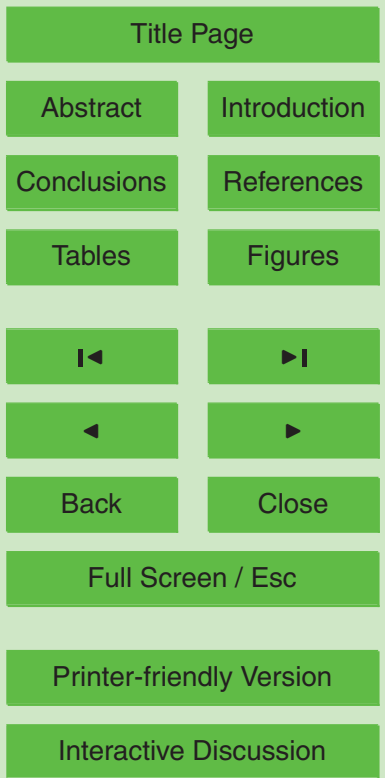


stormflow dominated catchments, these assumptions may not be valid. For example, local drainage direction of subsurface flow seems to be driven by subsurface topography and spatial variations in soil depth, rather than soil surface topography (McDonnell, 1990; Peters et al., 1995; Tani, 1997; Freer et al., 1997, 2002; Buttle et al., 2004; Tromp5 van Meerveld and McDonnell, 2006a,b). In most cases, soil matrix hydraulic conductivity decreases with increasing depth, but preferential flow may strongly affect how water travels through the soil, as shown by Noguchi et al. (1999) and Sidle et al. (2000). Covering a range of scales, these preferential flow pathways include, but are not limited to, root channels, organically rich horizons, and channels in the bedrock. The presence 10 of these features increases the complexity of the hillslope's hydrological functioning, in particular with respect to feedback mechanisms, storage effects, self-organization, hysteresis and threshold behavior (Phillips, 2003). Also, hydrologic conductivity values derived from soil core experiments can become almost useless if preferential flow pathways exist in the hillslope; transient water table response is not uniform over the 15 hillslope, but is governed by more complex behavior - see for example Seibert et al. (2003) and Tromp-van Meerveld and McDonnell (2006b).

Gaining a better understanding of subsurface stormflow generation is very important because practical issues such as flood forecasting, ecosystem management, water quality control and contaminant transport are all very much related to subsurface stormflow in this environment. For stable systems, a high degree of accuracy can be achieved with model types incorporating very little process knowledge (metric models, Wheater et al., 1993) with regard to the internal functioning of a hillslope or catchment (Andrews et al., 1995). However, improved representation of first-order controls on subsurface stormflow in our quantitative models will be crucial for making good predictions when conditions such as climate and landuse shift beyond the range of prior experience (Kirchner, 2006), as well as with problems for which the flow path of water is important. In such cases, accurate predictions can only be realistically expected from models based on process knowledge of subsurface stormflow.

In an effort to help advance the understanding of subsurface stormflow, Kirchner

HESSD

$6,5205-5241,2009$

Hillslope-scale, nonlinear model of subsurface stormflow

J. H. Spaaks et al.

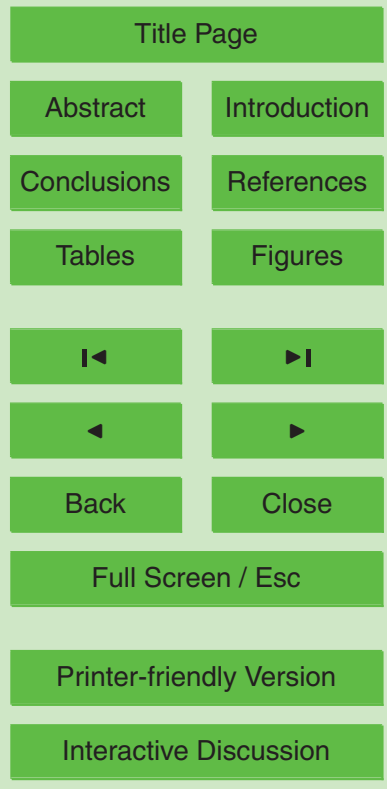


(2006) suggests five directions of research that, in his view and ours, offer good chances of success. In this paper, we pay special attention to two of his suggestions: (i) development of models that describe more consistently the nonlinear behavior observed in hillslope hydrologic systems; (ii) development of physically-based gray-box

5 models for describing the hydrological system at the hillslope scale, while recognizing that the governing equations at this scale may look different from those which govern the small-scale physics.

Following the downward approach (Klemeš, 1983; Sivapalan and Young, 2005), this study implements an iterative research cycle consisting of: (1) explicit formulation of 10 a hypothesis in a computer model structure; (2) designing and performing a virtual experiment, with which we test our hypothesis; (3) confronting the simulation results with our perceptual model (Beven, 2001); (4) introduction of additional complexity into our hypothesis, and going back to step 1.

\section{Methods}

15 Our philosophy is that we should carry out the steps of the iterative research cycle until our model is consistent with our collective field knowledge, or until the introduction of additional complexity is no longer warranted by the available data (Jakeman and Hornberger, 1993). To avoid problems with overparameterization and equifinality (e.g. Beven and Freer, 2001; Beven, 2006), each model must be fairly simple in terms of the model structure, its spatial discretization and the number of parameters, so that a meaningful assessment of its dynamics can be made. In a series of virtual experiments (Weiler and McDonnell, 2004), we ask the following questions:

1. For a lumped model, how is discharge affected by assuming that the pattern of transient groundwater within a model element is spatially continuous?

2. For a lumped model, how is discharge affected by assuming that the pattern of transient groundwater within a model element is spatially discontinuous?

HESSD

$6,5205-5241,2009$

Hillslope-scale, nonlinear model of subsurface stormflow

J. H. Spaaks et al.

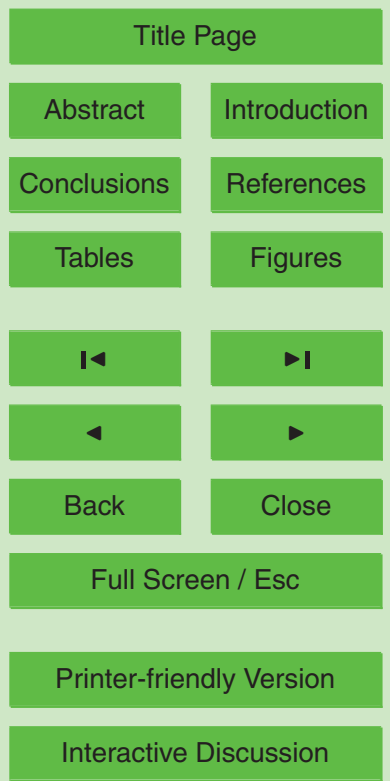


3. For a lumped model, how is discharge affected by assuming that the pattern of transient groundwater within a model element is spatially discontinuous and variable over time?

4. If we take two spatially distributed transect models of subsurface stormflow, one in which transient groundwater within a model element is spatially continuous, and one in which it is spatially discontinuous and variable over time, how do the patterns of lateral flow compare?

\subsection{Data}

To address these questions, we parameterize our evolving model with data from the 10 extensively studied hillslope at the Panola Mountain Research Watershed (Georgia, USA). The data include highly detailed information on precipitation and streamflow fluxes, as well as a map of soil depth derived from about 250 measurements covering the approximately $50 \times 20 \mathrm{~m}$ hillslope. We selected a major storm event, during which $59 \mathrm{~mm}$ of precipitation fell over a time span of about 1.5 days. Our streamflow data 15 has been recorded in the trench that forms the lower boundary of the research area, about $30 \mathrm{~m}$ upslope from an ephemeral stream. Though the original data discriminates between matrix flow and macropore flow for individual trench sections, we chose to use the total flow rate, calculated as the sum of matrix flow and macropore flow from all sections. For further details on the study site, the measuring devices, recorded variables, etc., please refer to Freer et al. (2002) and Tromp-van Meerveld et al. (2008), and references therein. Calibration of our models was done using the SCEM-UA algorithm (Vrugt et al., 2003; Spaaks, 2009). The total sum of squares between the observed and simulated discharge was used as the objective function.

\subsection{Model evaluation}

25 Following Wagener et al. (2004), we assess our evolving model based on its ability to reproduce past observations (performance), its uncertainty, and its underlying as-

\section{HESSD}

$6,5205-5241,2009$

Hillslope-scale, nonlinear model of subsurface stormflow

J. H. Spaaks et al.

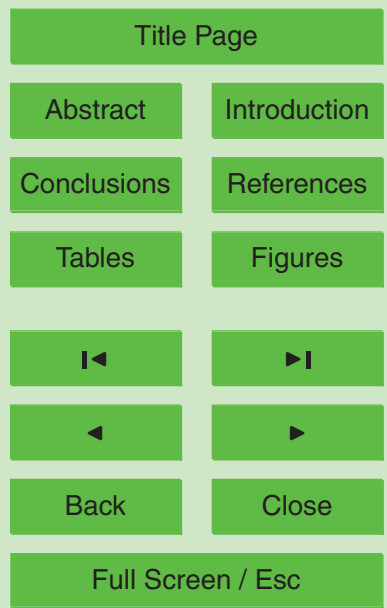

Printer-friendly Version

Interactive Discussion 
sumptions (model realism, Seibert and McDonnell, 2002). Our optimization procedure facilitates an easy assessment of both performance and uncertainty. With regard to model realism, we analyze to what extent our models are capable of reproducing the behavior of subsurface stormflow dominated hillslopes. Process studies from around 5 the world have established that this behavior is typically characterized by: a connectivity threshold-dominated flow regime, with significant flows occurring only after a certain threshold is exceeded (Tani, 1997; Tromp-van Meerveld and McDonnell, 2006a); highly skewed hydrographs with a steep increase in discharge when the threshold is exceeded (Tromp-van Meerveld and McDonnell, 2006a); a break in slope on the re10 cession limb (Hewlett and Hibbert, 1963; Harr, 1977); convergence of subsurface flow being driven by topography of a hydrologically impeding layer in the shallow subsurface (Freer et al., 1997, 2002); transient saturation occurring first in areas of shallow soil, and extending in the downslope direction (Tromp-van Meerveld and McDonnell, 2006b); transient saturation being a prerequisite for significant lateral subsurface flow 15 (Weiler et al., 2005); non-steady state groundwater table dynamics (Seibert et al., 2003).

\section{Virtual experiment 1}

\subsection{Rationale}

We model the Panola hillslope as a lumped tank model, in which the discharge rate is proportional to the pressure head in the tank. Although many hydrologically important variables are heterogeneous spatial fields, we assume that this averages out at the scale of the hillslope.

\section{HESSD}

$6,5205-5241,2009$

Hillslope-scale, nonlinear model of subsurface stormflow

J. H. Spaaks et al.

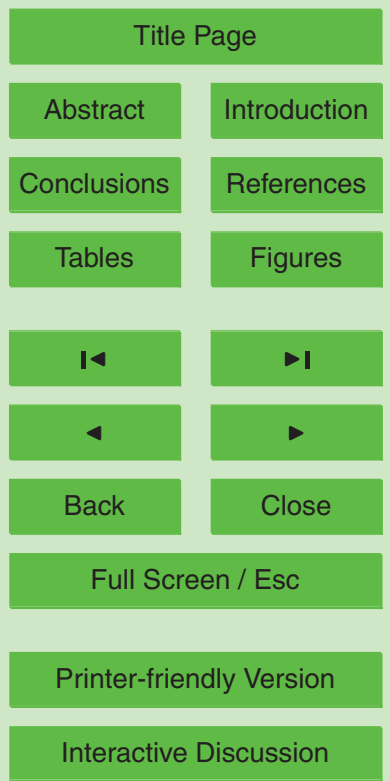




\subsection{Model $_{1}$ : homogeneous transient saturation, lumped}

\subsubsection{Tension storage}

The hillslope is treated as a spatial element of a certain area $A_{\text {elem }}\left[L^{2}\right]$, soil depth $d[L]$ and effective porosity $\phi$ equal to the volumetric water content at saturation $\theta_{\text {sat }}$

$5\left[L_{\text {water }}^{3} L_{\text {bulk }}^{-3}\right]$, which together determine the element's total pore space where soil water can be stored $V_{\max }$ (see Fig. 1):

$V_{\text {max }}=A_{\text {elem }} \cdot d \cdot \theta_{\text {sat }}$

When a completely saturated element is allowed to drain freely, part of the soil water that was initially present, will remain in the soil due to capillary forces. After all of 10 the excess soil water has been drained, the soil still contains a volumetric fraction $\theta_{\mathrm{fc}}$ $\left[L_{\text {water }}^{3} L_{\text {bulk }}^{-3}\right]$ of water (fc for "field capacity"). We divide the total pore space into 2 conceptual stores based on the value of $\theta_{\mathrm{fc}}$. As long as the element's actual volumetric water content $\theta_{\text {act }}\left[L_{\text {water }}^{3} L_{\text {bulk }}^{3}\right]$ is below $\theta_{\mathrm{fc}}$, all water present in that element is retained by the soil. If the below- $\theta_{\mathrm{fc}}$ store is completely full, any extra infiltration or lateral flow coming into the element will lead to emergence of excess water at the soil-impeding layer interface. The rate at which this happens is the volumetric emergence rate $E$ $\left[L^{3} \cdot T^{-1}\right]$.

\subsubsection{Emergence of tension-excess soil water}

When the below- $\theta_{\mathrm{fc}}$ store is full, any extra water added to the spatial element will

$E= \begin{cases}0 & 0 \leq \theta_{a c t} \leq \theta_{f c} \\ P+Q_{i n} & \theta_{f c}<\theta_{a c t} \leq \theta_{s a t}\end{cases}$

HESSD

$6,5205-5241,2009$

Hillslope-scale, nonlinear model of subsurface stormflow

J. H. Spaaks et al.

\section{Title Page}

Abstract Introduction

Conclusions References

Tables Figures

14

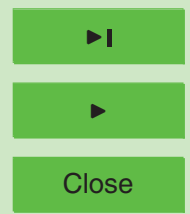

Back

Full Screen / Esc

Printer-friendly Version

Interactive Discussion 
where $E$ is the volumetric emergence rate $\left[L^{3} \cdot T^{-1}\right], P$ is the volumetric precipitation rate $\left[L^{3} \cdot T^{-1}\right]$ falling onto the spatial element and $Q_{\text {in }}$ is the lateral flow $\left[L^{3} \cdot T^{-1}\right]$ coming into the element from neighboring elements.

\subsubsection{Lateral flow}

5 When $\theta_{\text {act }}$ exceeds $\theta_{\mathrm{fc}}$, a transient water table is assumed to be present within the spatial element. The spatial gradient of transient water table drives the outflow into one of the neighboring downslope elements according to:

$Q=-K_{\mathrm{sat}} \cdot A_{\mathrm{flow}} \cdot \frac{\Delta H}{\Delta s}$

where $Q$ is the lateral flow $\left[L^{3} \cdot T^{-1}\right], K_{\text {sat }}$ is the saturated hydraulic conductivity $\left[L \cdot T^{-1}\right]$, ${ }_{10} A_{\text {flow }}$ is the cross-sectional area of flow $\left[L^{2}\right]$, and $\Delta H \cdot \Delta \mathrm{s}^{-1}$ is the spatial gradient in water table potential $\left[L \cdot L^{-1}\right]$. $H$ is calculated according to:

$H=z+\frac{V_{m}}{A_{\text {elem }} \cdot\left(\theta_{\text {sat }}-\theta_{\mathrm{fc}}\right)}$

where $H$ is the hydraulic head $[L]$ and $z$ is the elevation head of the impeding layer surface $[L]$. The subsurface drainage direction is determined using a steepest-descent

\subsubsection{Leakage of excess soil water into the bedrock}

Transport of transient groundwater from the above- $\theta_{\mathrm{fc}}$ store to the bedrock is governed by:

$V_{m}=\left(\theta_{\mathrm{sat}}-\theta_{\mathrm{fc}}\right) \cdot A_{\mathrm{elem}} \cdot(H-z)$
HESSD

$6,5205-5241,2009$

Hillslope-scale, nonlinear model of subsurface stormflow

J. H. Spaaks et al.

Title Page

Abstract Introduction

Conclusions References

Tables Figures

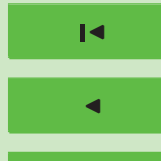

$>$ I

Back

Close

Full Screen / Esc

Printer-friendly Version

Interactive Discussion 
where $V_{m}$ is the volume of water $\left[L^{3}\right]$ in the above- $\theta_{\mathrm{fc}}$ store ( $m$ for mobile), $L$ is the volumetric leakage rate of transient groundwater to the bedrock $\left[L^{3} \cdot T^{-1}\right]$ and $K,\left[T^{-1}\right]$ is a proportionality constant.

\section{3.2.5 Recharge}

In the current formulation of our hypothesis, recharge is equal to emergence:

$R=E$

where $R$ represents the volumetric recharge rate $\left[L^{3} \cdot T^{-1}\right]$ of the saturated zone in a spatial element.

\subsubsection{Governing equation}

The volume of mobile water in each spatial element changes as a result of lateral flow, recharge, and leakage to the bedrock according to:

$\left.V_{m}\right|_{t+\Delta t}=\left.V_{m}\right|_{t}+\left(Q_{\text {out }}+R+L\right) \cdot \Delta t$

The current model formulation is hereafter referred to as Model $_{1}$.

\section{$6,5205-5241,2009$}

Hillslope-scale, nonlinear model of subsurface stormflow

J. H. Spaaks et al.

\section{$15 \quad 3.3$ Analysis}

Figure 2 shows rainfall-runoff observations and simulations. The discharge curve generated using the best parameter set is presented in subplot $\mathrm{B}$. The best performing

Title Page

Abstract Introduction

Conclusions References

Tables Figures

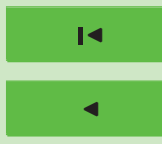

Back

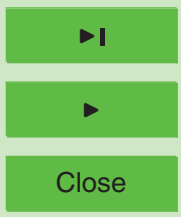

Full Screen / Esc

Printer-friendly Version

Interactive Discussion 
parameter set has been included for convenience in Table 1, along with the boundaries of the parameter search.

The figure shows that the model dynamics are different from the observed dynamics. More specifically, when transient saturation occurs at the beginning of Sector $B$ 5 (6 February, 06:30-20:15), the flow response is immediate and coincides with the observed timing of first flow. However, the simulated hydrograph is steeper compared to the observations made throughout Sector $\mathrm{B}$. When the observed discharge eventually starts to rise steeply at the beginning of Sector C (6 February, 20:15-22:15), the slope of observed discharge in that sector exceeds that of the simulated discharge from both 10 Sector B and C. Also, simulated peak flow precedes observed peak flow by about $3.6 \mathrm{~h}$, and when it occurs, it is only $56 \%$ of observed discharge $\left(0.164\right.$ and $0.291 \mathrm{~mm} \mathrm{hr}^{-1}$ for the "best simulation" run and observed discharge, respectively).

The observed falling limb can be divided into two parts based on local slope; during the first part (Sector D: 6 February, 22:15-7 February, 01:30), the observed slope is more negative compared to the second part (Sectors E and F: 7 February, 01:30-9 February, 23:45). This difference is not present in the simulated discharge. Summarizing the overall fit in a performance statistic, the best parameter set is associated with a relatively low Nash-Sutcliffe efficiency (Nash and Sutcliffe, 1970) of 0.60. This indicates that the current model formulation does not accurately capture the observed hydrological behavior. Table 2 presents an overview of typically observed dynamics and what aspects are captured by the current model formulation.

By making use of SCEM-UA's ability to provide information about parameter uncertainty, we also constructed a Bayesian probability interval using the last 1000 model parameterizations (shaded area in Fig. 2b). From the interval shown in Fig. $2 b$ it is clear that there is very little uncertainty caused by the parameters, as was expected given the relative simplicity of the model and the low number of parameters. Though the uncertainty may be small, the $[5,95]$ percentile contains only a few measurements besides those in Sector $A$.

\section{HESSD}

$6,5205-5241,2009$

Hillslope-scale, nonlinear model of subsurface stormflow

J. H. Spaaks et al.

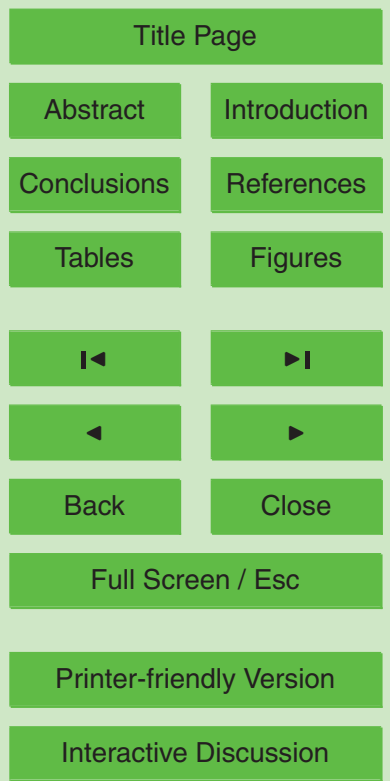




\subsection{Discussion}

From Eqs. (7) and (8) it can be inferred that the model assumes that the transient saturated layer is present everywhere in the spatial element (see Fig. 3a). This implies that once excess soil water starts to emerge at the soil-impeding layer interface, hillslope5 scale discharge will occur. This effect can be seen in the simulated discharge curve presented in Fig. $2 \mathrm{~b}$; as soon as the soil is at $\theta_{\text {act }}$ by the end of Sector A, discharge occurs. The overestimation of discharge in Sector B and the underestimation in Sectors $\mathrm{C}, \mathrm{D}$ and $\mathrm{E}$ is due to our calibration procedure: since we minimized the sum of squared deviations on all observation points, we ended up with what might be consid10 ered an average value for $K_{\text {sat }}$. This value does indeed minimize the global misfit, but it also yields a discharge curve that does not fit the observations in any part of the data set.

\section{Virtual experiment 2}

\subsection{Rationale}

15 In the previous experiment, it became apparent that the heterogeneity which is present at the sub-element scale does not average out at the hillslope scale. Representing transient saturation as a continuous layer is therefore not appropriate for hillslope-scale lumped modeling, since it leads to discharge that rises too steeply during the initial stages of the event and fails to reach the correct peak height. In the current experiment, we bring our implementation more in line with the updated perceptual model. To do so, we assume that the zone of transient saturation does not cover all parts of the soilimpeding layer interface (see Fig. 3b).

HESSD

$6,5205-5241,2009$

Hillslope-scale, nonlinear model of subsurface stormflow

J. H. Spaaks et al.

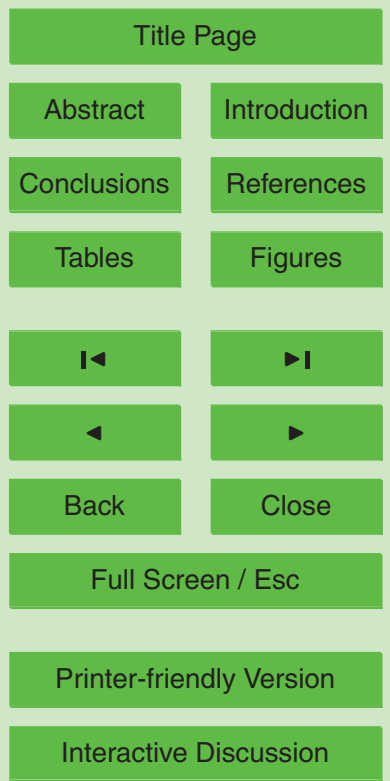




\subsection{Model $_{2}$ : heterogeneous transient saturation, lumped}

In this model, we reject the idea that a spatial element is internally homogeneous, or that the heterogeneity averages out at the scale of the hillslope. Instead, we embrace the idea of having a spatially discontinuous layer of transient saturation within an

5 element (see Fig. 3b). As a result, emerging excess water leaving the below- $\theta_{\mathrm{fc}}$ store cannot be added immediately to the above- $\theta_{\mathrm{fc}}$ store. Assuming that excess soil water emerges homogeneously from the bottom of the soil column, an instantaneous pulse of emerging excess soil water will not reach the above- $\theta_{\mathrm{fc}}$ store instantaneously, as was implied by Eq. (7). Instead, arrival of this water at the zone of transient saturation 10 will be delayed according to the frequency distribution of travel times $g(t)\left[T^{-1}\right]$ (e.g. Mazor and Nativ, 1992; Maloszewski and Zuber, 1993):

$g(t)=\frac{M(t)}{M_{t_{0}}}=\frac{M(t)}{\int_{t_{0}}^{+\infty} M(t) d t}$

where $M_{t_{0}}$ is the mass emerging as an instantaneous pulse at time $t_{0}$ and $M(t)$ represents the mass reaching the transient saturation zone at time $t$. In order to conserve 15 mass, the integral of $g(t)$ must equal unity:

$\int_{t_{0}}^{+\infty} g(t) d t=1$

In contrast to the conventional travel time distribution methodology, as described by McGuire and McDonnell (2006) among others, we do not use the convolution integral. Instead, we use a numerical approach to integrate Eq. (9) over the model time step $\Delta t$. 20 For the current model formulation we replace Eq. (7) by:

$R=\sum \int_{t-\tau_{i}}^{t-\tau_{i}+\Delta t} g\left(t-\tau_{i}\right) d t \cdot E_{i}$

\section{HESSD}

$6,5205-5241,2009$

Hillslope-scale, nonlinear model of subsurface stormflow

J. H. Spaaks et al.

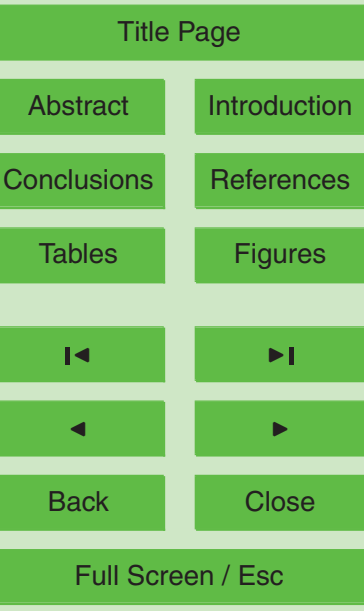

Printer-friendly Version

Interactive Discussion 
where $/$ is the set of iterations during which excess water emerged, $\tau_{i}$ is a shift in time pertaining to iteration $i, g\left(t-\tau_{i}\right)$ is the travel time distribution in the spatial element, and $E_{i}\left[L^{3} \cdot T^{-1}\right]$ is the volumetric rate at which excess water emerges during iteration $i$.

For simplicity, we assume a uniform travel time distribution according to:

${ }_{5} g\left(t-\tau_{i}\right)= \begin{cases}T^{-1} & t-\tau_{i}<T \\ 0 & t-\tau_{i} \geq T\end{cases}$

where $T[T]$ is the duration of the uniform travel time distribution. The current model formulation is hereafter referred to as $\mathrm{Model}_{2}$.

\subsection{Analysis}

Figure 4 shows rainfall-runoff observations and simulations. The discharge curve gen10 erated using the best parameter set is presented in subplot $\mathrm{B}$. The best performing parameter set has been included for convenience in Table 1, along with the boundaries of the parameter search.

For the best performing simulation, discharge behavior was not in accordance with observations in most sectors. For example, simulated flow in Sector B increased more steeply than what was observed, even though there was some improvement in that sector relative to the previous experiment. The model dynamics in Sectors $C$ and $D$ are completely different from the observations. The simulated peak is very smooth and has a relatively low magnitude and a long duration, rather than the high, short, and steep peak which was observed. Simulated discharge in these sectors actually becomes less steep rather than steeper, and therefore does not produce an accurate estimate of the timing of peak flow. Peak flow magnitude is just $68 \%$ of observed peak flow $\left(0.197\right.$ and $0.291 \mathrm{~mm} \mathrm{hr}^{-1}$ for the "best simulation" run and observed discharge, respectively). The best parameter set is associated with a relatively low Nash-Sutcliffe efficiency of 0.85 , which shows that the current model formulation does not accurately

HESSD

6, 5205-5241, 2009

Hillslope-scale, nonlinear model of subsurface stormflow

J. H. Spaaks et al.

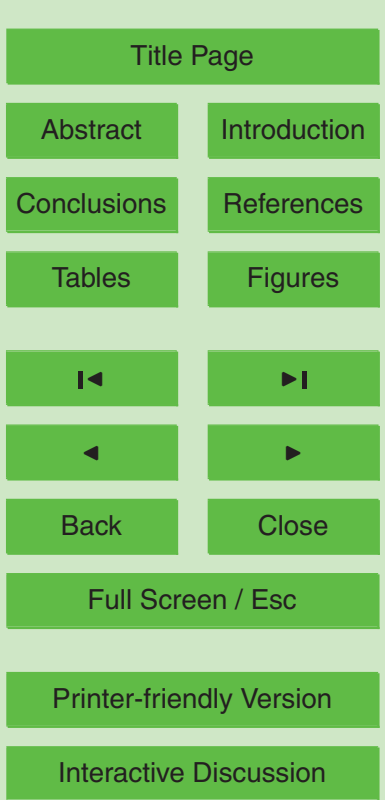


capture the observed hydrological behavior. Table 2 presents an overview of typically observed dynamics and what aspects are captured by the current model formulation.

Bayesian probability intervals were constructed in the same way as in the previous experiment. The parameters could be well identified from the discharge data. As in the 5 previous experiment, the probability interval is small. Compared to Model $_{1}$, it contains more observations throughout Sectors $\mathrm{E}$ and F.

\subsection{Discussion}

At first sight, the evaluation criteria in Table 2 do not suggest that the introduction of a heterogeneous distribution of transient saturation improved our representation of subsurface stormflow. However, if we focus on sector B, it appears that the simulated dynamics are similar to those of the observations in that sector, even though the fit is not as good as it could be. As in the first experiment, this is caused by our choice of objective function, which represents the model misfit as a single statistic based on data from all sectors, rather than a subset thereof. Had we run a set of simulations 15 based on Sectors A and B only, we would have found a parameter set that fitted the data very well. One could argue that $\mathrm{Model}_{2}$ therefore represents the processes at low flow (Sectors A and B) fairly accurately, but that the model does not yet incorporate processes acting under high flow conditions. In the next section, we will therefore investigate if the different behavior at low flow and high flow could be the result of

\section{Virtual experiment 3}

\subsection{Rationale}

We interpret the observed discharge as being generated by a mechanism that encompasses impedance to flow during the initial stages of the event, perhaps as a result of

\section{HESSD}

$6,5205-5241,2009$

Hillslope-scale, nonlinear model of subsurface stormflow

J. H. Spaaks et al.

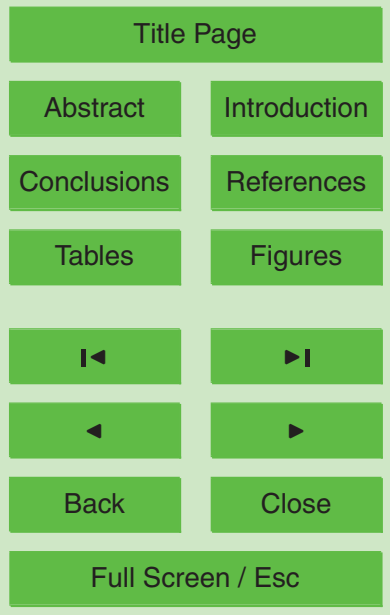

Printer-friendly Version

Interactive Discussion 
spatial organization of excess soil water (in particular with regard to the connectivity of wet patches). If the hillslope is indeed governed by such a mechanism, it could store incoming precipitation without generating much discharge during the initial stages of the event, while at the same time allowing for quick discharge of excess water once 5 the spatial element exceeds a certain wetness threshold. After this has occurred, the water that has accumulated in the spatial element under the inefficient regime is subsequently discharged, resulting in a large rise in subsurface stormflow.

\subsection{Model $_{3}:$ spatially and temporally heterogeneous transient saturation, lumped}

Our numerical approach to solving Eq. (9) enables the use of different travel time distributions, with which different states of the spatial element can be expressed. Figure 3c shows the surface of an impermeable layer, as well as a branched, spatially discontinuous saturated zone, which crosses the boundary of the spatial element and enters the downstream neighbor. Any soil water excess emerging in the spatial element is 15 assumed to leave the element through this preferential flow path. As the element becomes wetter, some preferential flow features that were previously inactive may become part of the subsurface flow network, effectively increasing the subsurface drainage density (see Fig. 3d). With the expansion of the subsurface flow network, the unsaturated soil volume around the zone of transient saturation becomes more ef-

20 ficiently connected to the downstream element. Consequently, transport of soil water internal to the element is governed by a shorter travel time distribution, resulting in more dynamic input-output behavior of the element as a whole, or equivalently, a reduced dampening effect of the input signal. We adapt Eq. (12) to represent unsaturated
HESSD

$6,5205-5241,2009$

Hillslope-scale, nonlinear model of subsurface stormflow

J. H. Spaaks et al.

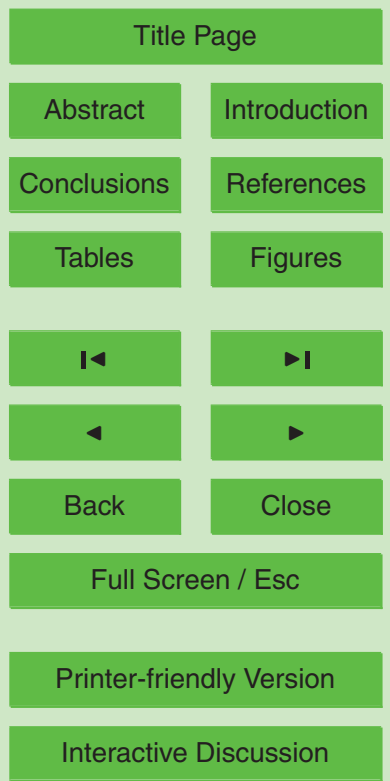


flow as a threshold-based travel time distribution:

HESSD

$g\left(t-\tau_{i}\right)= \begin{cases}T_{\mathrm{dry}}^{-1} & V_{m} \leq W T \wedge t-\tau_{i}<T_{\text {dry }} \\ 0 & V_{m} \leq W T \wedge t-\tau_{i} \geq T_{\text {dry }} \\ T_{\text {wet }}^{-1} & W T<V_{m} \wedge t-\tau_{i}<T_{\text {wet }} \\ 0 & W T<V_{m} \wedge t-\tau_{i} \geq T_{\text {wet }}\end{cases}$

with $T_{\text {dry }}$ and $T_{\text {wet }}[T]$ the duration of the uniform distribution under relatively dry and relatively wet conditions, respectively, and $W T$ the threshold wetness $\left[L^{3}\right]$ at which the 5 spatial element changes from dry to wet and vice versa. Further details on the setup of the model can be found in Table 1. The current model formulation is hereafter referred to as $\mathrm{Model}_{3}$.

\subsection{Analysis}

Figure 5 shows rainfall-runoff observations and simulations. The discharge curve generated using the best parameter set is presented in subplot $\mathrm{B}$. The best performing parameter set has been included for convenience in Table 1, along with the boundaries of the parameter search.

The figure shows that the best performing model simulation follows the observed behavior more closely and consistently than the two previous models. For example, the timing of first flow coincides with the observed timing, and simulated discharge remains relatively low throughout Sectors $A$ and $B$, even though more than $90 \%$ of total precipitation falls during this period. For the best performing simulation, peak discharge is $86 \%$ of observed discharge $\left(0.251\right.$ and $0.291 \mathrm{~mm} \mathrm{hr}^{-1}$ for the "best simulation" run and observed discharge, respectively). The simulated peak flow precedes the observed 20 peak flow by $0.75 \mathrm{~h}$.

The model behavior on the falling limb is very close to observed behavior except that the discharge curves generated by the current model do not have an inflection point 5221

6, 5205-5241, 2009

Hillslope-scale, nonlinear model of subsurface stormflow

J. H. Spaaks et al.

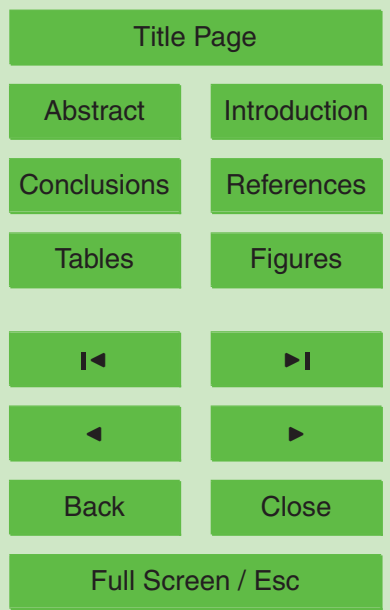

Printer-friendly Version

Interactive Discussion 
similar to that of the observed data. As a result of the closely matching behavior of simulated and observed dynamics, the Nash-Sutcliffe efficiency for the best performing discharge curve is 0.98 . Table 2 presents an overview of discharge dynamics as they are typically observed and the aspects which are captured by $\mathrm{Model}_{3}$.

5 The introduction of a threshold-based travel time distribution resulted in a very small Bayesian probability interval for this experiment. The parameters were identified without much difficulty.

\subsection{Discussion}

Despite the good performance of discharge realizations on the falling limb (Sectors $D$, $10 \mathrm{E}$, and F), a parameter set that could mimic the point of inflection occurring between Sectors $D$ and $E$ was not found. This may be the result of some unknown process that the model does not account for, such as hydrophobicity or the occurrence of air pockets in the soil. Alternatively, one could surmise that the hillslope acts as a number of separate units. Each unit may have a smooth falling limb, but depending on how they interact, a point of inflection may be present in the hillslope-scale hydrograph. We will investigate this further in the next section.

\section{Virtual experiment 4}

\subsection{Rationale}

If the hillslope acts as a number of elements, the hillslope-scale discharge dynamics

must be the result of how these elements interact. The purpose of the current experiment is therefore to assess whether model elements of different types give rise to specific spatial patterns of subsurface stormflow.
HESSD

$6,5205-5241,2009$

Hillslope-scale, nonlinear model of subsurface stormflow

J. H. Spaaks et al.

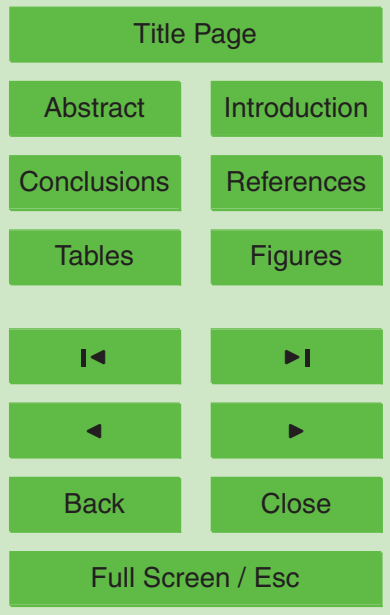

Printer-friendly Version

Interactive Discussion 


\subsection{Spatially and temporally heterogeneous transient saturation, spatially distributed}

We divide a transect of the Panola hillslope into eight spatial elements, with each element draining into its downstream neighbor. Local bedrock slope along the transect 5 ranges from 0.155 to $0.390 m_{z} m_{y}^{-1}$ and soil depth (see yellow bars in Fig. 6) varies from 0.180 to $1.39 \mathrm{~m}$. We again use SCEM-UA to calibrate the parameters of each element, using the same calibration data as in the first experiment. We assume that each spatial element has the same hydrologic properties so any particular set of parameters is applied to all spatial elements. In addition to the recorded precipitation, we 10 applied a small artificial event approximately two days after natural precipitation ceased (see Fig. 6). The precipitation intensity of the second, artificial storm was $3.00 \mathrm{~mm} \mathrm{hr}^{-1}$ throughout its 4-hr duration. The simple temporal structure of the artificial storm allowed us to make a better assessment of any differences between the models with regard to flow timing and magnitude.

\section{$15 \quad 6.3$ Analysis}

\subsubsection{Spatial elements of type Model $_{1}$}

At the beginning of the experiment, the soil moisture deficit is proportional to soil depth (see Table 3), and there is no mobile water since $\theta_{\mathrm{act}}<\theta_{\mathrm{fc}}$ for every element. Because of this, hillslope internal flow occurs first in the most shallow elements at $y=[42,30,36,6]^{1}$.

20 Even after emergence of excess water occurs in some elements, the resulting lateral flow is not large enough to disrupt the soil depth-driven pattern of first flow. Because the soil depth is relatively high at $y=18$, this element can store the largest volume of incoming water before excess soil water emerges. As a result, only a small volume of water is expelled as lateral flow.

\footnotetext{
${ }^{1}$ Spatial elements and their outflow curves are indicated by the same $y$-value to improve legibility.
}

\section{HESSD}

$6,5205-5241,2009$

Hillslope-scale, nonlinear model of subsurface stormflow

J. H. Spaaks et al.

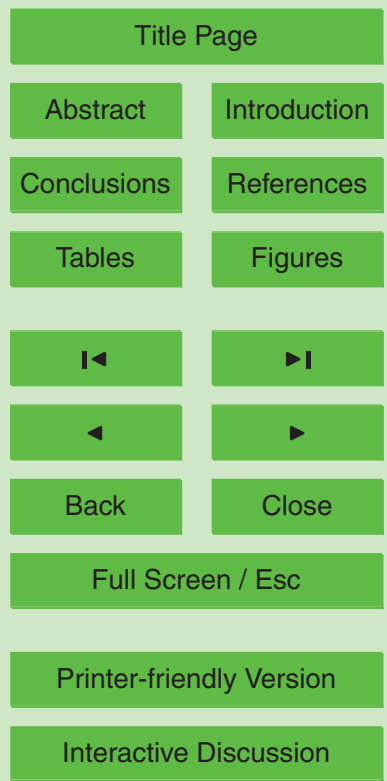


For this type of element, the start of the second precipitation event coincides exactly with the increase in hillslope internal flow, while the end of the precipitation event coincides exactly with maximum flow for all elements. Spatial differences in distributed flow are limited to the rate at which flow increases. Table 2 presents an overview of 5 what aspects of subsurface stormflow dominated systems are captured by the spatially distributed Model $_{1}$.

\subsubsection{Spatial elements of type $\mathrm{Model}_{3}$}

For Model $_{3}$, the spatial pattern of first flow is identical to that of Model $_{1}$ : spatial elements with shallow soils have the smallest absolute soil moisture deficit, so emergence occurs first in these elements. Since none of the elements contains mobile water at the start of the experiment $\left(\theta_{\mathrm{act}}<\theta_{\mathrm{fc}}\right)$, all elements are in the same state of wetness and therefore use the same travel time distribution. As a consequence, the spatial pattern of emergence also applies to recharge and therefore to timing of first flow.

At the onset of the second event, the upslope elements at $y=[24,30,36,42]$ as well as the downslope elements at $y=[0,6]$ have switched back again to the longer "dry" travel time distribution, while the midslope elements at $y=[12,18]$ are still in the responsive "wet" mode. This pattern of travel time distribution is related to the local impedance to lateral flow. The midslope elements have a very deep soil, hence their bedrock gradient is less steep compared to other elements. Because of this, water drains more slowly from these elements and they adhere longer to the "wet" travel time distribution. Because of the shorter travel time distribution, precipitation is more directly linked to lateral flow in these elements, therefore lateral flow starts to increase from the beginning of the second precipitation event, and continues rising until the end of the artificial storm, when peak flow occurs. All in all, the hydrological dynamics of the midslope 25 elements during the second event are very similar to that of Model $_{1}$.

By the time the artificial precipitation event begins, upslope elements have already switched back to the "dry" distribution. As a result, the emergence of excess soil water does not lead to a large increase in lateral flow from the element, although a low-flow
HESSD

6, 5205-5241, 2009

Hillslope-scale, nonlinear model of subsurface stormflow

J. H. Spaaks et al.

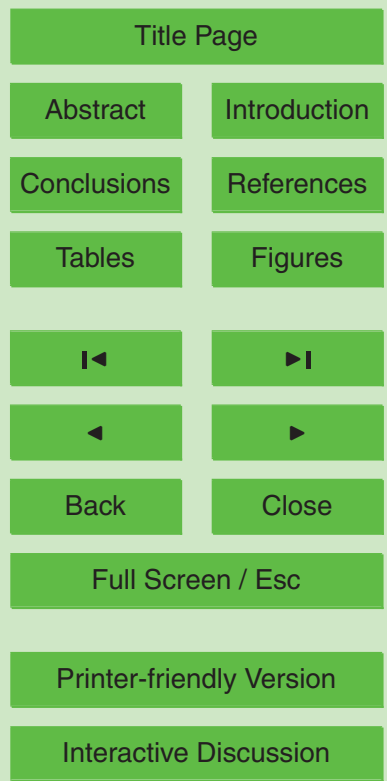


level is sustained throughout most of the simulation.

Contrary to this behavior, the downslope elements respond to the precipitation event in an entirely different, nonlinear fashion. At the beginning of the artificial precipitation event, these elements have drained enough water to be in the "dry" state. Therefore, 5 the precipitation event results in a sustained flow of low intensity for about $11.75 \mathrm{~h}$ after precipitation ceases; after that, enough water has accumulated in $V_{m}$ to make the element switch to the "wet" travel time distribution, which in turn leads to a steep increase in flow for these elements. Table 2 presents an overview of what aspects of subsurface stormflow dominated systems are captured by the spatially distributed $10 \mathrm{Model}_{3}$.

\subsection{Discussion}

In the concept underlying Model $_{1}$, discharge from a model element is directly related to the volume of emerging water. When applied to a transect of elements, as in the current experiment, this leads to patterns of subsurface stormflow that are less com15 plex in structure compared to patterns commonly encountered in the field (e.g. Seibert et al., 2003). Lateral flow in this concept acts as a smoothing function. Contrary to this, a model element governed by a nonlinear storage-flow relation, as in $\mathrm{Model}_{3}$, can generate lateral flow curves of different shapes as well as magnitudes. When such a concept is applied to a series of elements, the interaction between elements may yield 20 a pattern as simple as that of the more straightforward Model $_{1}$, but it may also yield a complex, heterogeneous pattern. This wider range of complexity can be achieved without compromising the model's parsimony by resorting to spatially distributed parameters.

The pattern of subsurface flow presented in Fig. $6 \mathrm{~b}$ should not be interpreted as an 25 accurate prediction of the real-world pattern; this study has been focused on the development of a model that would in principle be able to generate subsurface stormflow dynamics that are more in accordance with the heterogeneity typically observed in the field. Since the spatially distributed $\mathrm{Model}_{3}$ is very sensitive to changes in soil depth,
HESSD

$6,5205-5241,2009$

Hillslope-scale, nonlinear model of subsurface stormflow

J. H. Spaaks et al.

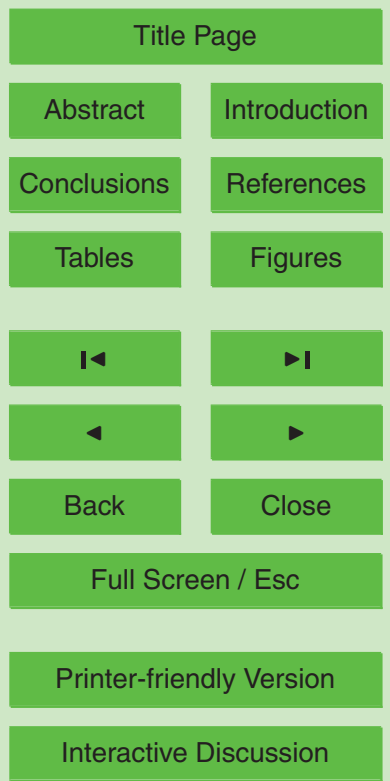


initial conditions and so on, relatively small errors imposed on the measurements can result in a rather different result. Moreover, our choice of where to position the transect and what grid cell size to use, also affects the results. Because of this, there is no purpose in drawing conclusions about how well the simulated patterns fit the real-world 5 patterns, other than in terms of the dynamics.

The results presented in Fig. 6 also constitute a plea for a more effective experimental design of distributed observation networks, and for stricter testing when discriminating between model structures, as argued by Kirchner et al. (1996), Mroczkowski et al. (1997), Kirchner (2006), and others. During the second event for example, the 10 flow curves in the midslope area $(y=[12,18])$ are similar for both models, even though the hydrological dynamics within the hillslope are very different for each model. When provided with data from the midslope section only, it is easy to see how a researcher could be lured into accepting either one of the models as an appropriate representation of reality. Even though the models cannot coexist, they can generate similar flow curves in parts of the hillslope. In order to distinguish one model from the other, we would need to introduce additional, spatially explicit measurements. With the data that has been presented for this study, however, it is unjustified to continue the Iterative Research Cycle.

\section{Summary and conclusions}

20 Many of the physically-based hydrological models that are currently in use, are based on an often implicit scaling assumption (Kirchner, 2006). This assumption states that small-scale heterogeneity upscales to the scale of a model grid cell, in such a way that the model's governing equation will differ in terms of its parameters, but not in terms of its structure. This, however, is not in line with typically observed behavior (see Table 2), as soil core scale behavior differs from hillslope scale behavior. To acknowledge the nonlinear properties associated with the hillslope hydrological system, we developed three hillslope-scale models of subsurface stormflow within an iterative research

\section{HESSD}

$6,5205-5241,2009$

Hillslope-scale, nonlinear model of subsurface stormflow

J. H. Spaaks et al.

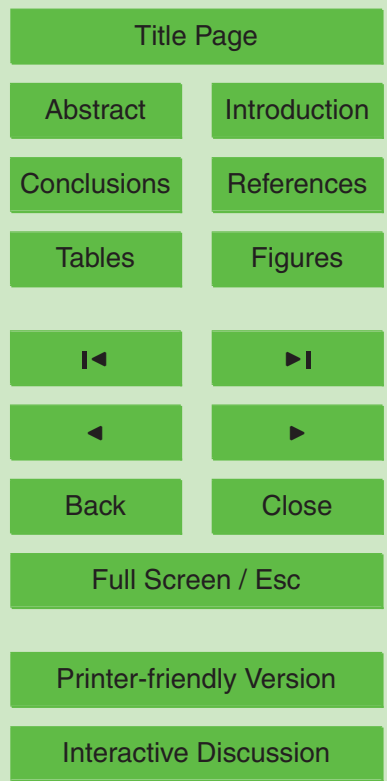


cycle. In our first experiment, we assumed that transient saturation occurs as a spatially continuous layer on top of the hydrologically impeding layer. When this concept is applied at the hillslope scale, the timing of first hillslope-scale discharge coincides with the emergence of transient saturation. Due to the implicit connectivity within the 5 hillslope, transport of excess water is relatively unobstructed. As a result, discharge rises too steeply during the early stages of an event, which leads to peak flow reaching only $56 \%$ of observed discharge.

In our second experiment, we rejected the idea that transient saturation occurs as a spatially continuous layer within the hillslope. Instead, water that emerges at the im10 peding layer must travel laterally through the unsaturated zone before it reaches the saturated zone, from where it can be discharged. The transport time through the unsaturated zone was modeled by calibrating a one-parameter frequency distribution of travel times. To maintain flexibility, this travel time distribution was solved in a numerical scheme rather than by using the convolution integral. The global fit improved relative to that of Model $_{1}$, but in Sectors C and D the simulated dynamics still deviated substantially from the observed dynamics. In Sectors B, E and F, the model successfully captured the discharge dynamics, but the fit was negatively affected by our use of a single objective function operating on all data points.

In experiment 3, we built on the experience gained from virtual experiment 2 by

introducing a threshold-based travel time distribution. In this way, we were able to separate the parameters which were relevant under relatively dry conditions from those which were relevant under relatively wet conditions. We hypothesized that at low flow, patches of excess water were present within the hillslope, but that they were not sufficiently connected to each other and to the trench face to yield large flow rates. After a certain threshold was exceeded, however, these connections were sufficiently active to account for the steep, large rise in subsurface stormflow. With this model formulation, we achieved a good fit as well as good dynamics in all sectors, since the parameters that govern the behavior at low discharge rates were separated from those at high discharge. Although the model captured almost all of the aspects of the observed
HESSD

6, 5205-5241, 2009

Hillslope-scale, nonlinear model of subsurface stormflow

J. H. Spaaks et al.

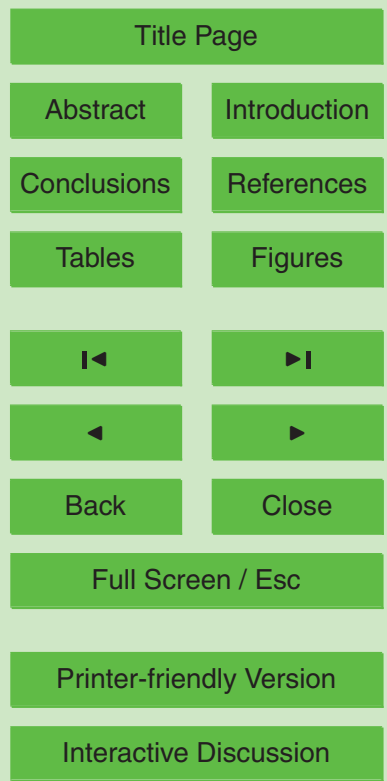


hydrograph, the break in slope on the falling limb was not reproduced by the model.

After having assessed these three models in a lumped setup, we then compared Model $_{1}$ to Model $_{3}$ in a spatially explicit setup, to determine what patterns of subsurface stormflow were possible with each model. We found that Model $_{1}$ tended to generate 5 relatively smooth, steady state-like spatial patterns. With Model $_{3}$, we were able to generate more complex patterns, in which lateral flow could be concurrently increasing and decreasing in different parts of the hillslope. The pattern generated by $\mathrm{Model}_{3}$ was more in concordance with our perceptual model of subsurface stormflow than that of Model $_{1}$. Also, the observed dynamics are better represented by Model $_{3}$ compared to 10 Model $_{1}$. Even so, it is unlikely that the simulated pattern precisely fits patterns observed at Panola, because it remains difficult to relate observations to model entities.

We realize that our approach is not the only way in which nonlinear processes can be incorporated into a hydrological model. However, we believe that the development and subsequent testing of various nonlinear models will lead to an inspiring confrontation of model results with preconceptions about hydrological mechanisms. As such, these models can help us explore new ways of thinking about hillslope hydrology, which will ultimately lead to improved understanding of the subsurface stormflow process.

Acknowledgements. This study was conducted within the Virtual Laboratory for e-Science project (http://www.vl-e.nl) which is supported by a BSIK grant from the Dutch Ministry of Ed20 ucation, Culture and Science and the ICT innovation program of the Dutch Ministry of Economic Affairs. The Panola data was kindly provided by Ilja Tromp-van Meerveld. We thank Jake Peters for the continued support of the Panola research site. The authors wish to thank Hanne Laine for reviewing an earlier draft of this manuscript. Chris Graham, Luisa Hopp and Takahiro Sayama are thanked for the useful discussions along the way.

Andrews, R., Diederich, J., and Tickle, A. B.: Survey and critique of techniques for extracting rules from trained artificial neural networks, Knowledge-Based Systems, 8, 373-389, doi: 10.1016/0950-7051(96)81920-4, 1995. 5208

\section{8}

HESSD

$6,5205-5241,2009$

Hillslope-scale, nonlinear model of subsurface stormflow

J. H. Spaaks et al.

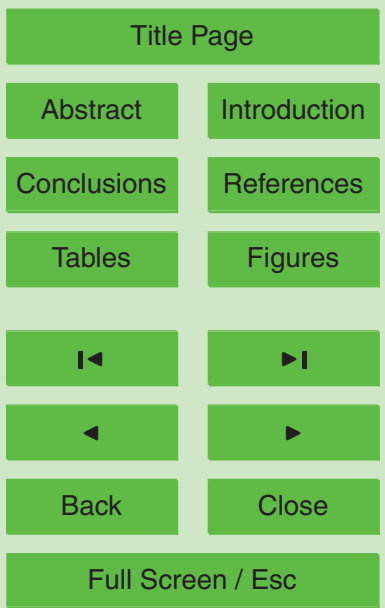

Printer-friendly Version

Interactive Discussion 
Betson, R. P.: What is watershed runoff?, J. Geophys. Res., 69, 1541-1552, 1964. 5207

Beven, K. J.: Rainfall-runoff modelling - the primer, John Wiley and Sons Ltd., Chichester, 2001. 5209

Beven, K. J.: A manifesto for the equifinality thesis, J. Hydrol., 320, 18-36, doi:10.1016/j.jhydrol. 2005.07.007, 2006. 5209

Beven, K. J. and Freer, J.: Equifinality, data assimilation, and uncertainty estimation in mechanistic modelling of complex environmental systems using the GLUE methodology, J. Hydrol., 249, 11-29, 2001. 5209

Buttle, J. M., Dillon, P. J., and Eerkes, G. R.: Hydrologic coupling of slopes, riparian zone and streams: an example from the Canadian Shield, J. Hydrol., 287, 161-177, doi:10.1016/j. jhydrol.2003.09.022, 2004. 5208

Dunne, T. and Black, R. D.: An experimental investigation of runoff production in permeable soils, Water Resour. Res., 6, 478-490, 1970. 5207

Freer, J., McDonnell, J. J., Beven, K. J., Brammer, D., Burns, D., Hooper, R. P., and Kendal, C.: Topographic controls on subsurface storm flow at the hillslope scale for two hydrologically distinct small catchments, Hydrol. Process., 11, 1347-1352, 1997. 5207, 5208, 5211

Freer, J., McDonnell, J. J., Beven, K. J., Peters, N. E., Burns, D. A., Hooper, R. P., and Aulenbach, B.: The role of bedrock topography on subsurface stormflow, Water Resour. Res., 38, 1269, doi:10.1029/2001WR000872, 2002. 5207, 5208, 5210, 5211

20

Harr, R. D.: Water flux in soil and subsoil on a steep forested slope, J. Hydrol., 33, 37-58, 1977. 5211

Hewlett, J. D. and Hibbert, A. R.: Moisture and energy conditions within a sloping soil mass during drainage, J. Geophys. Res., 68, 1081-1087, 1963. 5211

Hewlett, J. D. and Hibbert, A. R.: Factors affecting the response of small watersheds to precipitation in humid areas, in: Proceedings of the International Symposium on Forest Hydrology (1965), Pennsylvania State University, edited by: Sopper, W. E. and Lull, H. W., Pergamon, 275-290, 1967. 5207

Horton, R. E.: The rôle of infiltration in the hydrological cycle, in: Transactions of the American Geophysical Union, 14, 446-460, 1933. 5207

30 Hursh, C. R.: Appendix B - report of the sub-committee on subsurface-flow, in: Transactions of the American Geophysical Union, 743-746, 1944. 5207

Hursh, C. R. and Brater, E. F.: Separating storm-hydrographs from small drainage-areas into surface- and subsurface-flow, in: Transactions of the American Geophysical Union, 3, 863-
HESSD

$6,5205-5241,2009$

Hillslope-scale, nonlinear model of subsurface stormflow

J. H. Spaaks et al.

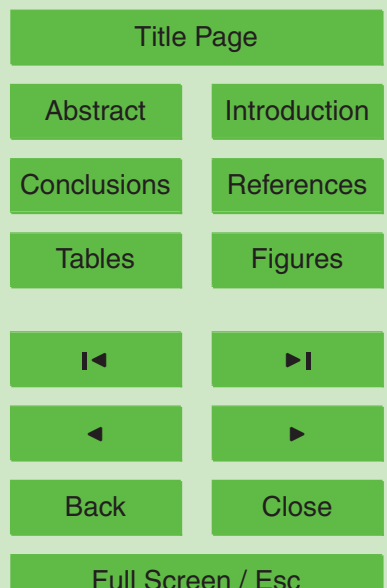

Full Screen / Esc

Printer-friendly Version

Interactive Discussion 
$871,1941.5207$

Jakeman, A. J. and Hornberger, G. M.: How much complexity is warranted in a rainfall-runoff model?, Water Resour. Res., 29, 2637-2649, 1993. 5209

Jones, J. A. A.: Soil piping and stream channel initiation, Water Resour. Res., 7, 602-610, 1971. 5207

Kirchner, J. W.: Getting the right answers for the right reasons: linking measurements, analyses, and models to advance the science of hydrology, Water Resour. Res., 42, W03S04, doi:10.1029/2005WR004362, 2006. 5208, 5226

Kirchner, J. W., Hooper, R. P., Kendall, C., Neal, C., and Leavesly, G.: Testing and validating environmental models, Sci. Total Environ., 183, 33-47, 1996. 5226

Klemeš, V.: Conceptualization and scale in hydrology, J. Hydrol., 65, 1-23, in: Scale Problems in Hydrology, Rodríguez-Iturbe, I. and Gupta, V. K. (Guest-Editors), 1983. 5209

Maloszewski, P. and Zuber, A.: Principles and practice of calibration and validation of mathematical models for the interpretation of environmental tracer data, Adv. Water Res., 16,

Mazor, E. and Nativ, R.: Hydraulic calculation of groundwater flow velocity and age: examination of the basic premises, J. Hydrol., 138, 211-222, 1992. 5217

McDonnell, J. J.: A rationale for old water discharge through macropores in a steep, humid catchment, Water Resour. Res., 26, 2821-2832, 1990. 5207, 5208

20

McDonnell, J. J.: Where does the water go when it rains? Moving beyond the variable source area concept of rainfall-runoff response, Hydrol. Process., 17, 1869-1875, invited commentary, 2003. 5207

McGuire, K. J. and McDonnell, J. J.: A review and evaluation of catchment transit time modeling, J. Hydrol., 330, 543-563, doi:10.1016/j.jhydrol.2006.04.020, 2006. 5217

Mosley, M. P.: Streamflow generation in a forested watershed, New Zealand, Water Resour. Res., 15, 795-806, 1979. 5207

Mroczkowski, M., Raper, G. P., and Kuczera, G.: The quest for more powerful validation of conceptual catchment models, Water Resour. Res., 33, 2325-2335, 1997. 5226

Nash, J. E. and Sutcliffe, J. V.: River flow forecasting through conceptual models. Part 1 - a

30 discussion of principles, J. Hydrol., 10, 282-290, doi:10.1016/0022-1694(70)90255-6, 1970. 5215

Noguchi, S., Tsuboyama, Y., Sidle, R. C., and Hosoda, I.: Morphological characteristics of marcopores and the distribution of preferential flow pathways in a forested slope segment,
HESSD

$6,5205-5241,2009$

\section{Hillslope-scale, nonlinear model of subsurface stormflow}

J. H. Spaaks et al.

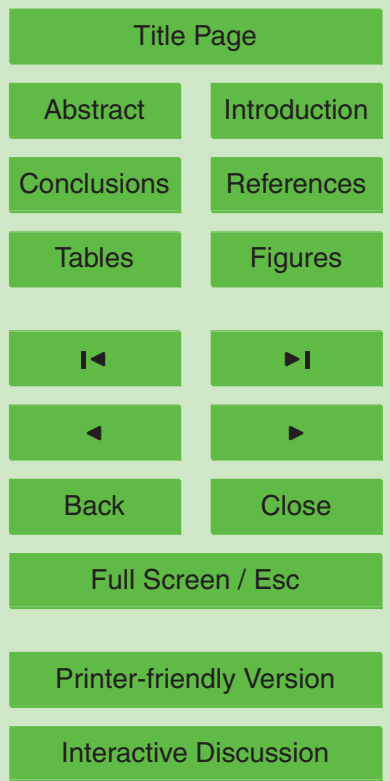


Soil Sci. Soc. Am. J., 63, 1413-1423, 1999. 5208

O'Callaghan, J. F. and Mark, D. M.: The extraction of drainage networks from digital elevation data, Comput. Vision Graph., 28, 323-344, 1984. 5213

Peters, D. L., Buttle, J. M., Taylor, C. H., and LaZerte, B. D.: Runoff production in a forested, shallow soil, Canadian Shield basin, Water Resour. Res., 31, 1291-1304, 1995. 5207, 5208

Phillips, J. D.: Sources of nonlinearity and complexity in geomorphic systems, Prog. Phys. Geog., 27, 1-23, 2003. 5208

Rodhe, A.: The Origin of Streamwater Traced by Oxygen-18, Ph.D. thesis, Uppsala University, Uppsala, Sweden, 260 pp., 1987. 5207

10 Seibert, J. and McDonnell, J. J.: On the dialog between experimentalist and modeler in catchment hydrology: Use of soft data for multicriteria model calibration, Water Resour. Res., 38, 1241, doi:10.1029/2001WR000978, 2002. 5211

Seibert, J., Bishop, K., Rodhe, A., and McDonnell, J. J.: Groundwater dynamics along a hillslope: A test of the steady state hypothesis, Water Resour. Res., 39, 1014, doi: 10.1029/2002WR001404 2003. 5207, 5208, 5211, 5225

Sidle, R. C., Tsuboyama, Y., Noguchi, S., Hosoda, I., Fujieda, M., and Shimizu, T.: Stormflow generation in steep forested headwaters: a linked hydrogeomorphic paradigm, Hydrol. Process., 14, 369-385, 2000. 5207, 5208

Sivapalan, M. and Young, P. C.: Downward approach to hydrological model development, in: Encyclopedia of Hydrological Sciences, edited by: Anderson, M. G. and McDonnell, J. J., John Wiley, Hoboken, NJ, vol. 3, 2081-2100, 2005. 5209

Spaaks, J. H.: SCEM-UA parameter optimization toolbox for MATLAB, online available at: http: //code.google.com/p/scemua/, (software), 2009. 5210

Tani, M.: Runoff generation processes estimated from hydrological observations on a steep forested hillslope with a thin soil layer, J. Hydrol., 200, 84-109, 1997. 5207, 5208, 5211

Tromp-van Meerveld, H. J. and McDonnell, J. J.: Threshold relations in subsurface stormflow 1. a 147-storm analysis of the Panola hillslope, Water Resour. Res., 42, W02410, doi:10.1029/ 2004WR003778, 2006a. 5208, 5211

Tromp-van Meerveld, H. J. and McDonnell, J. J.: Threshold relations in subsurface stormflow 2. 30 the fill and spill hypothesis, Water Resour. Res., 42, W02411, doi:10.1029/2004WR003800, 2006b. 5207, 5208, 5211

Tromp-van Meerveld, H. J., James, A. L., McDonnell, J. J., and Peters, N. E.: A reference data set of hillslope rainfall-runoff response, Panola Mountain Research Watershed, United
HESSD

$6,5205-5241,2009$

\section{Hillslope-scale, nonlinear model of subsurface stormflow}

J. H. Spaaks et al.

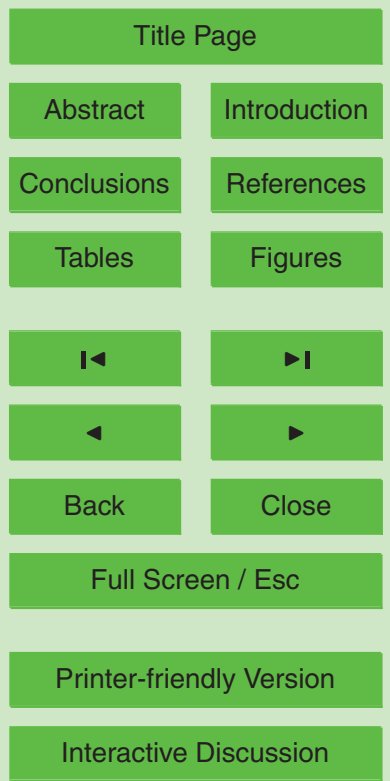


States, Water Resour. Res., 44, W06502, doi:10.1029/2007WR006299, http://www.sfu.ca/ PanolaData/, last access: April 2008. 5210

Vrugt, J. A., Gupta, H. V., Bouten, W., and Sorooshian, S.: A Shuffled Complex Evolution Metropolis algorithm for optimization and uncertainty assessment of hydrologic model parameters, Water Resour. Res., 39, 1201, doi:10.1029/2002WR001642, 2003. 5210

Wagener, T., Wheater, H. S., and Gupta, H. V.: Rainfall-runoff modeling in gauged and ungauged catchments, Imperial College Press, London, ISBN 978-1-86094-466-6, 2004. 5210

Weiler, M. and McDonnell, J. J.: Virtual experiments: a new approach for improving process conceptualization in hillslope hydrology, J. Hydrol., 285, 3-18, 2004. 5209

10 Weiler, M., McDonnell, J. J., Tromp-van Meerveld, I., and Uchida, T.: Subsurface stormflow, in: Encyclopedia of Hydrological Sciences, edited by: Anderson, M. G. and McDonnell, J. J., John Wiley and Sons, Ltd., 1719-1732, ISBN 0-471-49103-9, 2005. 5207, 5211

Weyman, D. R.: Measurements of the downslope flow of water in a soil, J. Hydrol., 20, 267-288, 1973. 5207

Wheater, H. S., Jakeman, A. J., and Beven, K. J.: Progress and directions in rainfall-runoff modelling, in: Modelling Change in Environmental Systems, edited by: Jakeman, A. J., Beck, M. B., and McAllen, M. J., John Wiley, Chichester, 101-132, 1993. 5208

HESSD

$6,5205-5241,2009$

\section{Hillslope-scale, nonlinear model of subsurface stormflow}

J. H. Spaaks et al.

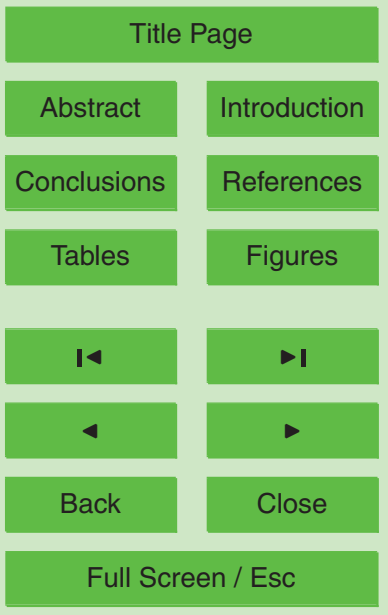

Printer-friendly Version

Interactive Discussion 
Table 1. Model configuration for virtual experiments 1, 2 and 3.

\begin{tabular}{|c|c|c|c|}
\hline parameter & description & value & units \\
\hline \multicolumn{4}{|l|}{ Constants } \\
\hline$t_{\text {start }}$ & Start date and time of simulation & 6 February, 2002 00:00 & $\mathrm{N} / \mathrm{A}$ \\
\hline$t_{\text {end }}$ & End date and time of simulation & 9 February, 2002 23:45 & $\mathrm{N} / \mathrm{A}$ \\
\hline$P_{\text {total }}$ & Total precipitation depth & 58.9 & $\mathrm{~mm}$ \\
\hline$I_{\max }$ & Maximum precipitation intensity & 7.11 & $\mathrm{~mm} \mathrm{hr}^{-1}$ \\
\hline$\nabla z$ & $\begin{array}{l}\text { Spatial gradient of the impeding } \\
\text { layer }\end{array}$ & 0.272 & - \\
\hline$\theta_{\text {sat }} \equiv \phi$ & Effective porosity & 0.500 & - \\
\hline$\theta_{\mathrm{fc}}$ & Water content at field capacity & 0.150 & - \\
\hline$\theta_{\text {act, init }}$ & $\begin{array}{l}\text { Initial actual volumetric water } \\
\text { content }\end{array}$ & 0.135 & - \\
\hline$d$ & Soil depth & 0.628 & $\mathrm{~m}$ \\
\hline \multicolumn{4}{|c|}{ Virtual experiment 1} \\
\hline$K_{\text {sat }}$ & $\begin{array}{l}\text { Hydraulic conductivity for soil } \\
\text { water transport between spatial } \\
\text { elements }\end{array}$ & $287(8.33,833)$ & $\mathrm{mm} \mathrm{hr}^{-1}$ \\
\hline$K_{l}$ & $\begin{array}{l}\text { Factor controlling efficiency of } \\
\text { flow to the bedrock sink. }\end{array}$ & $2.83 \times 10^{-2}\left(4.17 \times 10^{-4}, 8.33 \times 10^{-2}\right)$ & $\mathrm{hr}^{-1}$ \\
\hline \multicolumn{4}{|c|}{ Virtual experiment 2} \\
\hline$K_{\text {sat }}$ & $\begin{array}{l}\text { Hydraulic conductivity for soil } \\
\text { water transport between spatial } \\
\text { elements }\end{array}$ & $744\left(18.0,1.80 \times 10^{5}\right)$ & $\mathrm{mm} \mathrm{hr}^{-1}$ \\
\hline$K_{l}$ & $\begin{array}{l}\text { Factor controlling efficiency of } \\
\text { flow to the bedrock sink. }\end{array}$ & $3.90 \times 10^{-2}\left(1.44 \times 10^{-3}, 14.4\right)$ & $\mathrm{hr}^{-1}$ \\
\hline$T$ & $\begin{array}{l}\text { Duration of the travel time distri- } \\
\text { bution }\end{array}$ & $11.2\left(5.04 \times 10^{-2}, 252\right)$ & $\mathrm{hr}$ \\
\hline \multicolumn{4}{|c|}{ Virtual experiment 3} \\
\hline$K_{\text {sat }}$ & $\begin{array}{l}\text { Hydraulic conductivity for soil } \\
\text { water transport between spatial } \\
\text { elements }\end{array}$ & $694\left(34.2,1.37 \times 10^{4}\right)$ & $\mathrm{mm} \mathrm{hr}^{-1}$ \\
\hline$K_{l}$ & $\begin{array}{l}\text { Factor controlling efficiency of } \\
\text { flow to the bedrock sink. }\end{array}$ & $3.75 \times 10^{-2}\left(1.93 \times 10^{-3}, 0.770\right)$ & $\mathrm{hr}^{-1}$ \\
\hline$T_{\text {wet }}$ & $\begin{array}{l}\text { Duration of the travel time distri- } \\
\text { bution under wet conditions }\end{array}$ & $0.851(0.00,6.43)$ & $\mathrm{hr}$ \\
\hline$T_{\text {dry }}$ & $\begin{array}{l}\text { Duration of the travel time distri- } \\
\text { bution under dry conditions }\end{array}$ & $26.3(2.41,965)$ & $\mathrm{hr}$ \\
\hline$W T$ & $\begin{array}{l}\text { Wetness threshold at which a } \\
\text { spatial element switches from } \\
\text { one travel time distribution to an- } \\
\text { other }\end{array}$ & $9.92(1.00,15.0)$ & $\mathrm{m}^{3}$ \\
\hline
\end{tabular}

HESSD

$6,5205-5241,2009$

\section{Hillslope-scale, nonlinear model of subsurface stormflow}

J. H. Spaaks et al.

\section{Title Page}

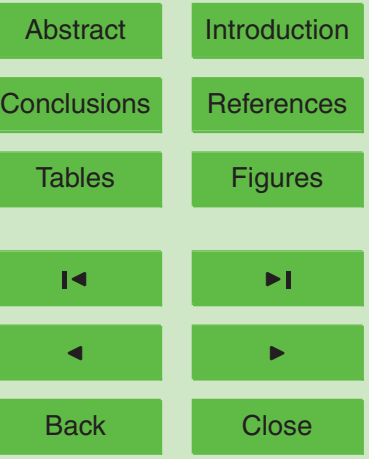

Full Screen / Esc

Printer-friendly Version

Interactive Discussion 


\section{HESSD}

$6,5205-5241,2009$

Table 2. Typically observed dynamics and to what extent they are captured by the model formulations presented in this study.

\begin{tabular}{|c|c|c|c|c|c|}
\hline \multirow[b]{2}{*}{ Evaluation criteria } & \multicolumn{3}{|c|}{ lumped } & \multicolumn{2}{|c|}{ transect } \\
\hline & Model $_{1}$ & Model $_{2}$ & Model $_{3}$ & Model $_{1}$ & Model $_{3}$ \\
\hline $\begin{array}{l}\text { Connectivity-threshold dominated flow } \\
\text { regime }\end{array}$ & No & No & Yes & No & Yes \\
\hline $\begin{array}{l}\text { Steep increase in discharge after threshold is } \\
\text { exceeded }\end{array}$ & No & No & Yes & No & Yes \\
\hline Break in slope on the recession limb & No & No & No & No & No \\
\hline $\begin{array}{l}\text { Subsurface topography driven convergence } \\
\text { of subsurface stormflow }\end{array}$ & $\mathrm{N} / \mathrm{A}$ & $\mathrm{N} / \mathrm{A}$ & $\mathrm{N} / \mathrm{A}$ & Yes & Yes \\
\hline $\begin{array}{l}\text { Transient saturation occurring first in areas of } \\
\text { shallow soil, extending in the downslope di- } \\
\text { rection }\end{array}$ & $\mathrm{N} / \mathrm{A}$ & $\mathrm{N} / \mathrm{A}$ & $\mathrm{N} / \mathrm{A}$ & Yes & Yes \\
\hline $\begin{array}{l}\text { Transient saturation as a prerequisite for lat- } \\
\text { eral subsurface flow }\end{array}$ & Yes & Yes & Yes & Yes & Yes \\
\hline $\begin{array}{l}\text { Non-steady state groundwater table dynam- } \\
\text { ics }\end{array}$ & $\mathrm{N} / \mathrm{A}$ & $\mathrm{N} / \mathrm{A}$ & $\mathrm{N} / \mathrm{A}$ & No & Yes \\
\hline
\end{tabular}

\section{Hillslope-scale, nonlinear model of subsurface stormflow}

J. H. Spaaks et al.

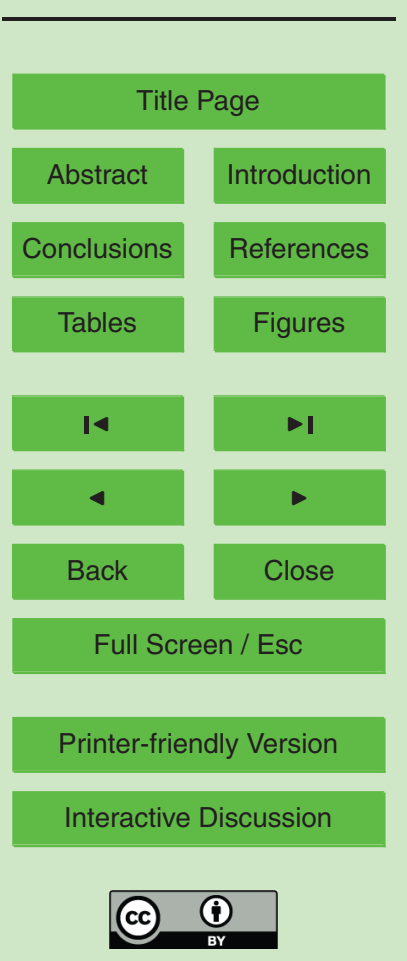


Table 3. Model configuration for virtual experiment 4.

\begin{tabular}{|c|c|c|c|}
\hline parameter & description & value* & units \\
\hline \multicolumn{4}{|l|}{ Constants } \\
\hline$t_{\text {start }}$ & Start date and time of simulation & 6 February, 2002 00:00 & $\mathrm{N} / \mathrm{A}$ \\
\hline \multirow[t]{2}{*}{$t_{\text {end }}$} & End date and time of simulation & 9 February, $200223: 45^{\circ}$ & $\mathrm{N} / \mathrm{A}$ \\
\hline & & 12 February, 2002 23:45 & $\mathrm{N} / \mathrm{A}$ \\
\hline$P_{\text {total }}$ & Total precipitation depth & $\begin{array}{c}58.9^{\diamond} \\
58.9+12.0^{\diamond}\end{array}$ & $\begin{array}{l}\mathrm{mm} \\
\mathrm{mm}\end{array}$ \\
\hline$I_{\max }$ & Maximum precipitation intensity & 7.11 & $\mathrm{~mm} \mathrm{hr}^{-1}$ \\
\hline$\nabla z$ & $\begin{array}{l}\text { Spatial gradient of the impeding } \\
\text { layer }\end{array}$ & $0.155-0.390$ & - \\
\hline \multirow{3}{*}{$\begin{array}{c}\theta_{\text {sat }} \equiv \phi \\
\theta_{\text {fc }} \\
\theta_{\text {act,init }}\end{array}$} & Effective porosity & 0.500 & - \\
\hline & Water content at field capacity & 0.150 & - \\
\hline & $\begin{array}{l}\text { Initial actual volumetric water } \\
\text { content }\end{array}$ & 0.135 & - \\
\hline$d$ & Soil depth & $0.180-1.39^{\bullet}$ & $\mathrm{m}$ \\
\hline \multicolumn{4}{|c|}{ Virtual experiment 4 , model element type 1} \\
\hline$K_{\text {sat }}$ & $\begin{array}{l}\text { Hydraulic conductivity for soil } \\
\text { water transport between spatial } \\
\text { elements }\end{array}$ & $9.43\left(4.17 \times 10^{-2}, 417\right)$ & $\mathrm{mm} \mathrm{hr}^{-1}$ \\
\hline$K_{l}$ & $\begin{array}{l}\text { Factor controlling efficiency of } \\
\text { flow to the bedrock sink. }\end{array}$ & $2.67\left(4.17 \times 10^{-5}, 0.417\right)$ & $\mathrm{hr}^{-1}$ \\
\hline \multicolumn{4}{|c|}{ Virtual experiment 4 , model element type 3} \\
\hline$K_{\text {sat }}$ & $\begin{array}{l}\text { Hydraulic conductivity for soil } \\
\text { water transport between spatial } \\
\text { elements }\end{array}$ & $350\left(10.2,1.08 \times 10^{4}\right)$ & $\mathrm{mm} \mathrm{hr}^{-1}$ \\
\hline$K_{l}$ & $\begin{array}{l}\text { Factor controlling efficiency of } \\
\text { flow to the bedrock sink. }\end{array}$ & $3.25 \times 10^{-2}\left(1.44 \times 10^{-3}, 1.44\right)$ & $\mathrm{hr}^{-1}$ \\
\hline$T_{\text {dry }}$ & $\begin{array}{l}\text { Duration of the travel time distri- } \\
\text { bution under dry conditions }\end{array}$ & $25.1(0.00,184)$ & $\mathrm{hr}$ \\
\hline$T_{\text {wet }}$ & $\begin{array}{l}\text { Duration of the travel time distri- } \\
\text { bution under wet conditions }\end{array}$ & $0.827(0.00,27.6)$ & $\mathrm{hr}$ \\
\hline$W T$ & $\begin{array}{l}\text { Wetness threshold at which a } \\
\text { spatial element switches from } \\
\text { one travel time distribution to an- } \\
\text { other }\end{array}$ & $4.91 \times 10^{-2}(0.00,1.00)$ & $\mathrm{m}^{3}$ \\
\hline \multicolumn{4}{|c|}{$\begin{array}{l}\text { Parameter space search limits in brackets. } \\
\text { See Fig. } 6 \text { for the spatial distribution of soil depth. } \\
\text { Calibration event. } \\
\diamond \text { Evaluation event. }\end{array}$} \\
\hline
\end{tabular}

HESSD

$6,5205-5241,2009$

\section{Hillslope-scale, nonlinear model of subsurface stormflow}

\section{J. H. Spaaks et al.}

\section{Title Page}

\section{Abstract}

Introduction

Conclusions

References

Tables

Figures

14

4

Back

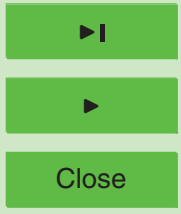

Full Screen / Esc

Printer-friendly Version

Interactive Discussion 


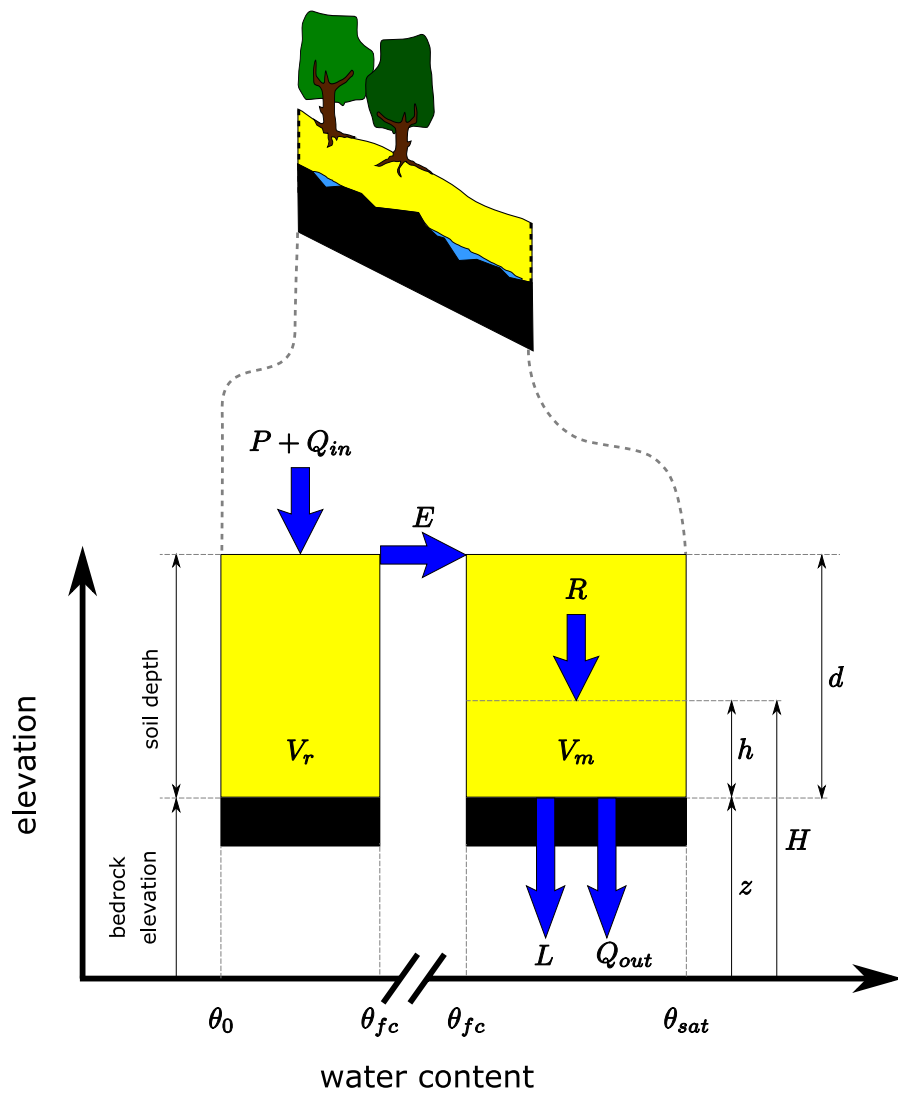

\section{HESSD}

6, 5205-5241, 2009

Hillslope-scale, nonlinear model of subsurface stormflow

J. H. Spaaks et al.

Title Page

Abstract

Conclusions

Tables

14

4

Back

Full Screen / Esc

Printer-friendly Version

Interactive Discussion 


\section{HESSD}

6, 5205-5241, 2009

A

A
B

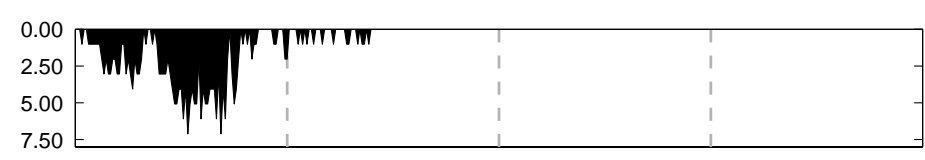

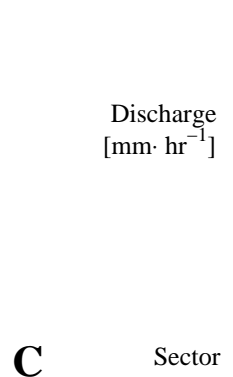

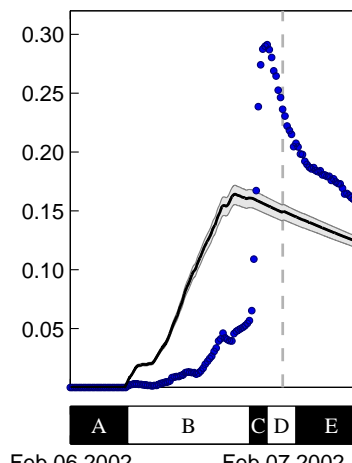

Feb.06,2002
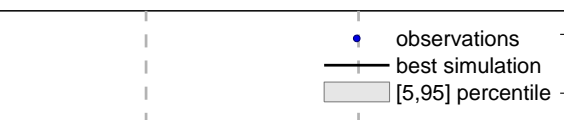

।
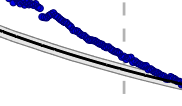

।
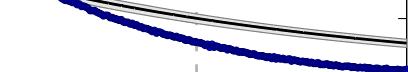

Feb.09,2002

\section{Hillslope-scale, nonlinear model of subsurface stormflow}

J. H. Spaaks et al.

Title Page

Abstract Introduction

Conclusions

References

Tables

Figures

14

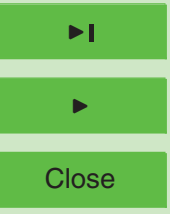

Back

Full Screen / Esc

Printer-friendly Version

Interactive Discussion 


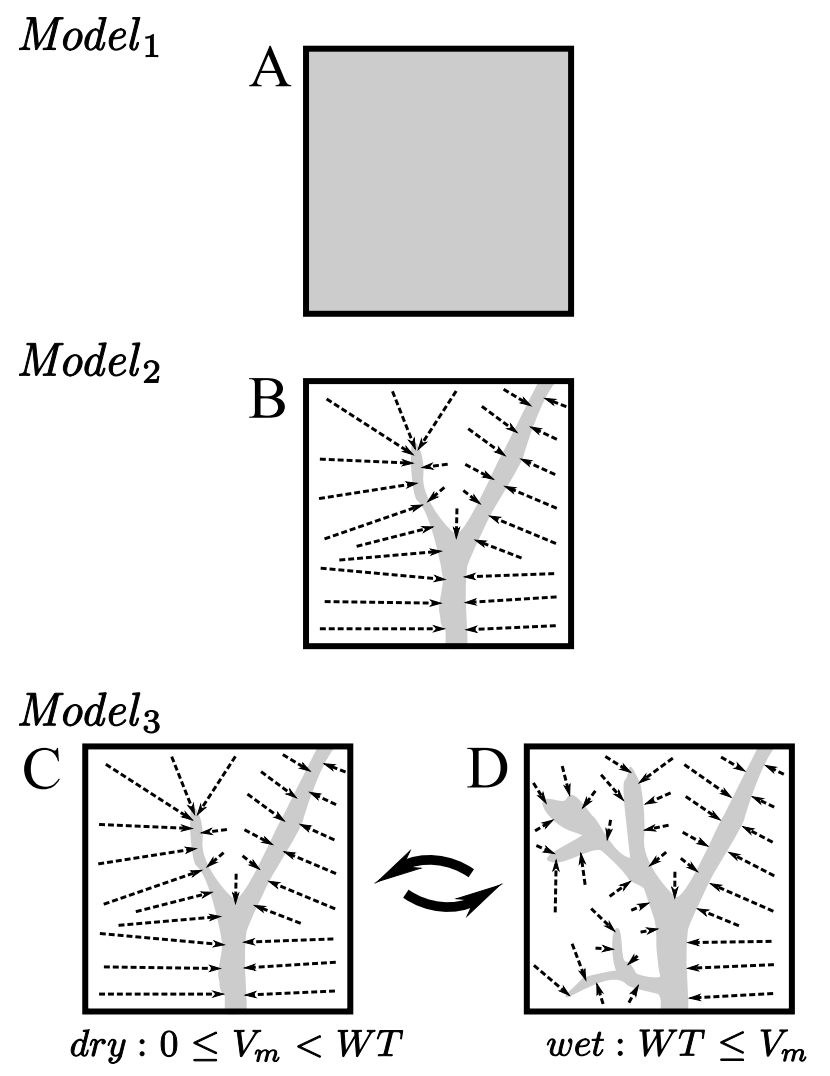

\section{HESSD}

6, 5205-5241, 2009

\section{Hillslope-scale, nonlinear model of subsurface stormflow}

J. H. Spaaks et al.

\section{Title Page}

Abstract

Conclusions

\section{Tables}

14

4

Back
Introduction

References

Figures

$\rightarrow 1$

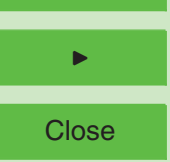

Full Screen / Esc

Printer-friendly Version

Fig. 3. Top views of grid cells showing the hydrologically impeding layer with saturated zone (shaded area) and unsaturated zone (white) for Model ${ }_{1}$, Model ${ }_{2}$ and Model $_{3}$. Dashed arrows in plots (B), (C) and (D) represent transport through the unsaturated zone. Note the relative abundance of short arrows in plot (D), compared to plot (C). 


\section{HESSD}

6, 5205-5241, 2009

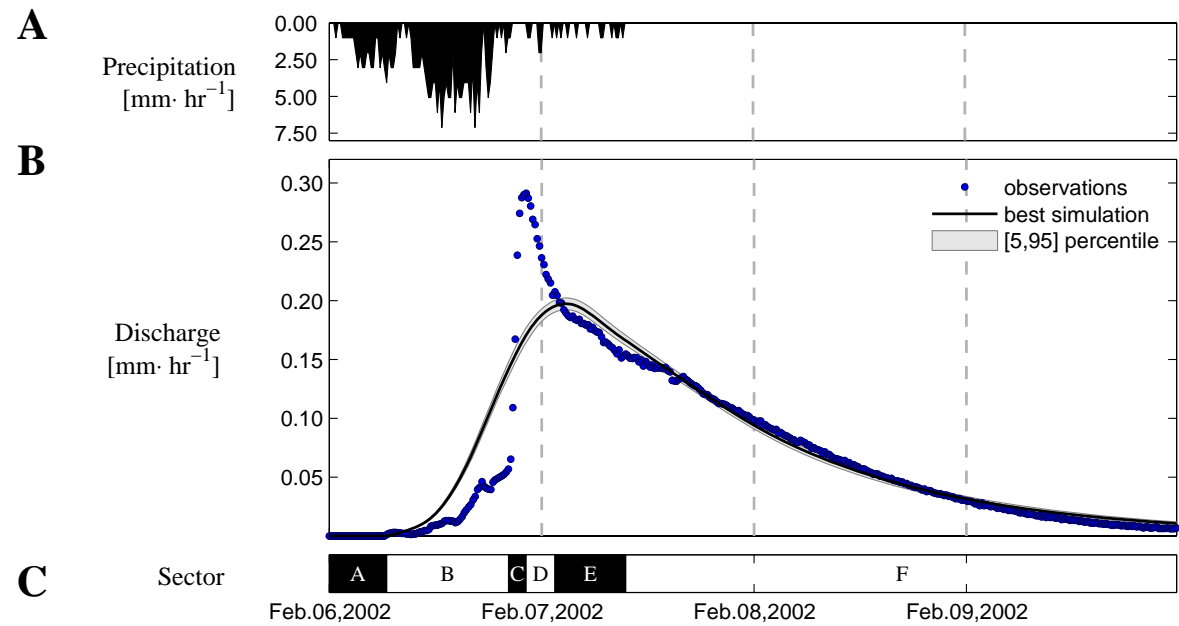

\section{Hillslope-scale, nonlinear model of subsurface stormflow \\ J. H. Spaaks et al.}

Title Page

Abstract

Conclusions

Tables

References

14

4

Back

Full Screen / Esc

Printer-friendly Version

Interactive Discussion 


\section{HESSD}

$6,5205-5241,2009$

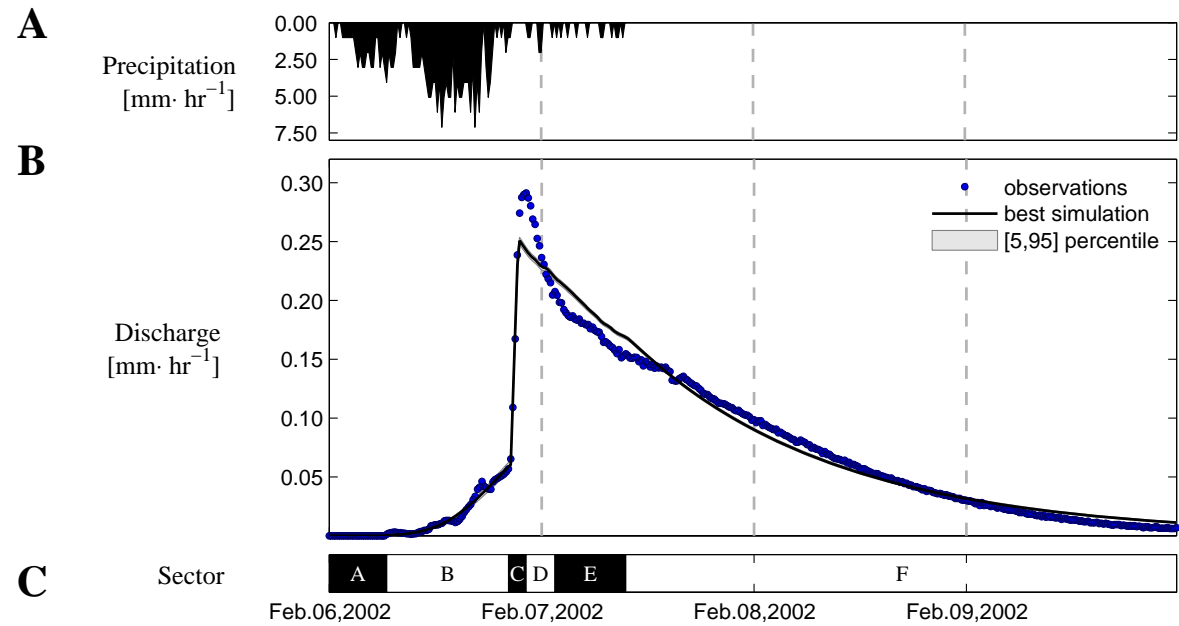

\section{Hillslope-scale, nonlinear model of subsurface stormflow \\ J. H. Spaaks et al.}

Title Page

Abstract Introduction

Conclusions References

Tables Figures

14 $<$

Fig. 5. Virtual experiment 3. (A) Observed precipitation. (B) Discharge observations, best simulation, and Bayesian probability interval for $\mathrm{Model}_{3}$. (C) Sector identifier.
Back

\section{Close}

Full Screen / Esc

Printer-friendly Version

Interactive Discussion 


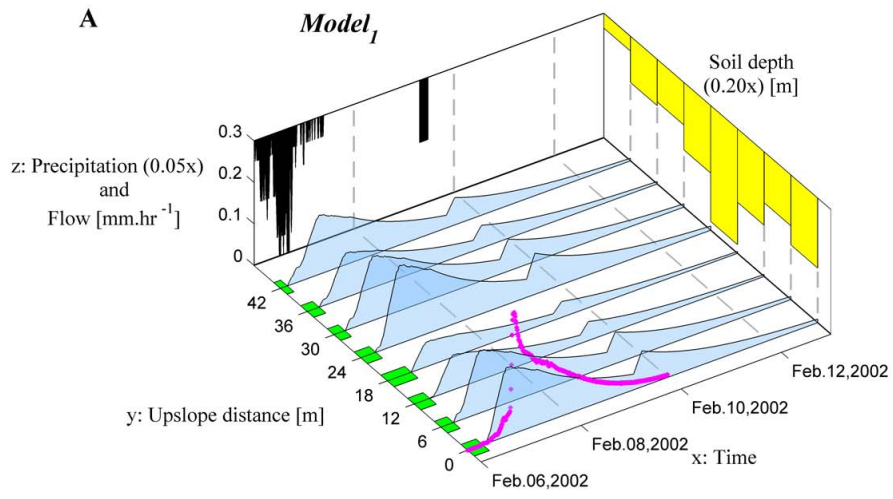

\section{HESSD}

$6,5205-5241,2009$

\section{Hillslope-scale, nonlinear model of subsurface stormflow}

J. H. Spaaks et al.

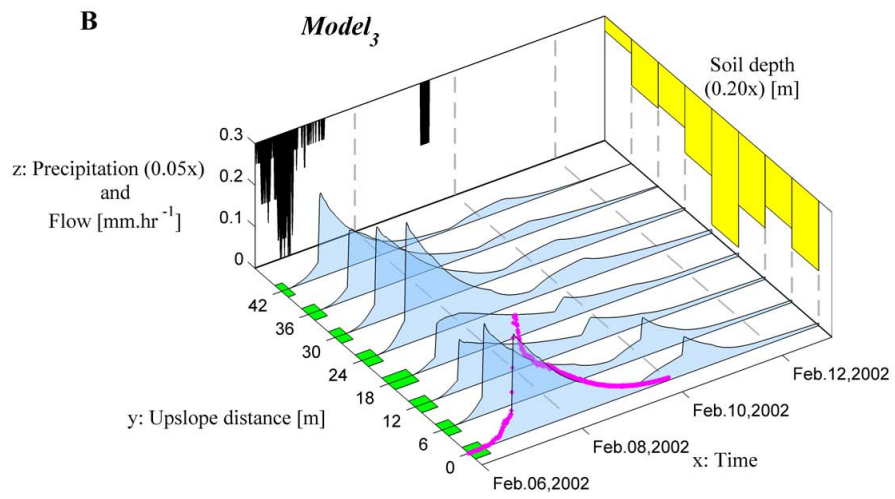

Title Page

Abstract Introduction

Conclusions

References

Tables

Figures

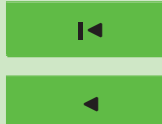

$>1$

Back

Close

Full Screen / Esc

Fig. 6. Virtual experiment 4. Upper-left back pane, black: observed and artificial precipitation intensity $(0.05 \mathrm{x})$. Upper-right back pane, yellow: hillslope soil depth $(0.20 \mathrm{x})$. Bottom pane, blue: distributed flow curves of subsurface stormflow along the hillslope transect, as simulated by model elements of type (A) Model $_{1}$, and (B) Model ${ }_{3}$. Green bars coming from $\mathrm{X}=0$ represent the time to first flow. Magenta dots are observations of hillslope-scale discharge as used in the calibration.

Printer-friendly Version

Interactive Discussion 